\title{
Thyroid Autoantibodies in Pregnancy: Their Role, Regulation and Clinical Relevance
}

\author{
Francis S. Balucan, Syed A. Morshed, and Terry F. Davies \\ Thyroid Research Unit, Mount Sinai School of Medicine and James J. Peters VA Medical Center, \\ 130 West Kingsbridge Road, Bronx, New York, NY 10468, USA \\ Correspondence should be addressed to Francis S. Balucan; f.balucan@gmail.com
}

Received 1 August 2012; Revised 11 March 2013; Accepted 20 March 2013

Academic Editor: Elizabeth N. Pearce

Copyright ( 2013 Francis S. Balucan et al. This is an open access article distributed under the Creative Commons Attribution License, which permits unrestricted use, distribution, and reproduction in any medium, provided the original work is properly cited.

\begin{abstract}
Autoantibodies to thyroglobulin and thyroid peroxidase are common in the euthyroid population and are considered secondary responses and indicative of thyroid inflammation. By contrast, autoantibodies to the TSH receptor are unique to patients with Graves' disease and to some patients with Hashimoto's thyroiditis. Both types of thyroid antibodies are useful clinical markers of autoimmune thyroid disease and are profoundly influenced by the immune suppression of pregnancy and the resulting loss of such suppression in the postpartum period. Here, we review these three types of thyroid antibodies and their antigens and how they relate to pregnancy itself, obstetric and neonatal outcomes, and the postpartum.
\end{abstract}

\section{Introduction: Pregnancy and Tolerance}

Immune tolerance in pregnancy is the absence of a maternal immune response against the fetus and placenta, leading to unusually successful "allografts" as the fetus is genetically different from the mother. This adaptive phenomenon involves all aspects of the immune response [1], but in this review, we will concentrate on those aspects directly and indirectly related to thyroid autoantibodies.

\section{Thyroid Autoantibodies to Thyroglobulin and Thyroid Peroxidase}

2.1. Discovery. In 1925 , Hektoen and Schulhof $[2,3]$ in their animal studies with thyroglobulin $(\mathrm{Tg})$ precipitins proposed that $\mathrm{Tg}$ provoked an immune response. Later, it was noticed that $\gamma$-globulins were increased in patients with Hashimoto's thyroiditis, which were then theorized to reflect autoantibodies against $\mathrm{Tg}[4]$. With this information and animal studies from Witebsky et al. [5] that thyroiditis could be induced by $\mathrm{Tg}$ in rabbits, Campbell et al. (1956) demonstrated the possible role of antibodies to Tg in Hashimoto's thyroiditis [6]. The subsequent development of clinical assays for both $\mathrm{Tg}$ and $\mathrm{Tg}-\mathrm{Ab}[7]$ improved our information about the pathology of the disease, and it is clear that $\mathrm{Tg}$ is a major autoantigen in both Hashimoto's and Graves' diseases and its immunogenicity varies with its degree of iodination [8]. Wholegenome linkage studies have shown that the chromosome $8 \mathrm{q} 24$ locus [9], which contains the Tg gene, is linked to the development of autoimmune thyroiditis [10] suggesting that polymorphisms in the gene are an important mechanism for provoking the immune response [11].

Thyroid peroxidase (TPO) was first discovered as a thyroidal microsomal autoantigen by Belyavin and Trotter in 1957 [12]. It took 20 years for this autoantigen to be characterized as TPO by Portmann et al. [13]. TPO-Abs are present in much higher titers than $\mathrm{Tg}$ - $\mathrm{Ab}$ since, unlike $\mathrm{Tg}$ the TPO enzyme is membrane bound and not secreted into the circulation and so does not cause TPO-Ab to be removed or blocked from being measured.

2.2. Structure of the Thyroid Antigens. Both $\mathrm{Tg}$ and TPO are essential in the synthesis and secretion of thyroid hormones (Figure 1). The thyroglobulin gene on $8 \mathrm{q} 24.2$ codes for a large dimeric glycoprotein of $330 \mathrm{kd}$ for each dimer [14, 15]. Tyrosine residues of $\mathrm{Tg}$ homodimers are iodinated in the apical border of the thyroid cell to form monoiodotyrosine (MIT) and di-iodotyrosine (DIT) [9]. The importance of Tg 


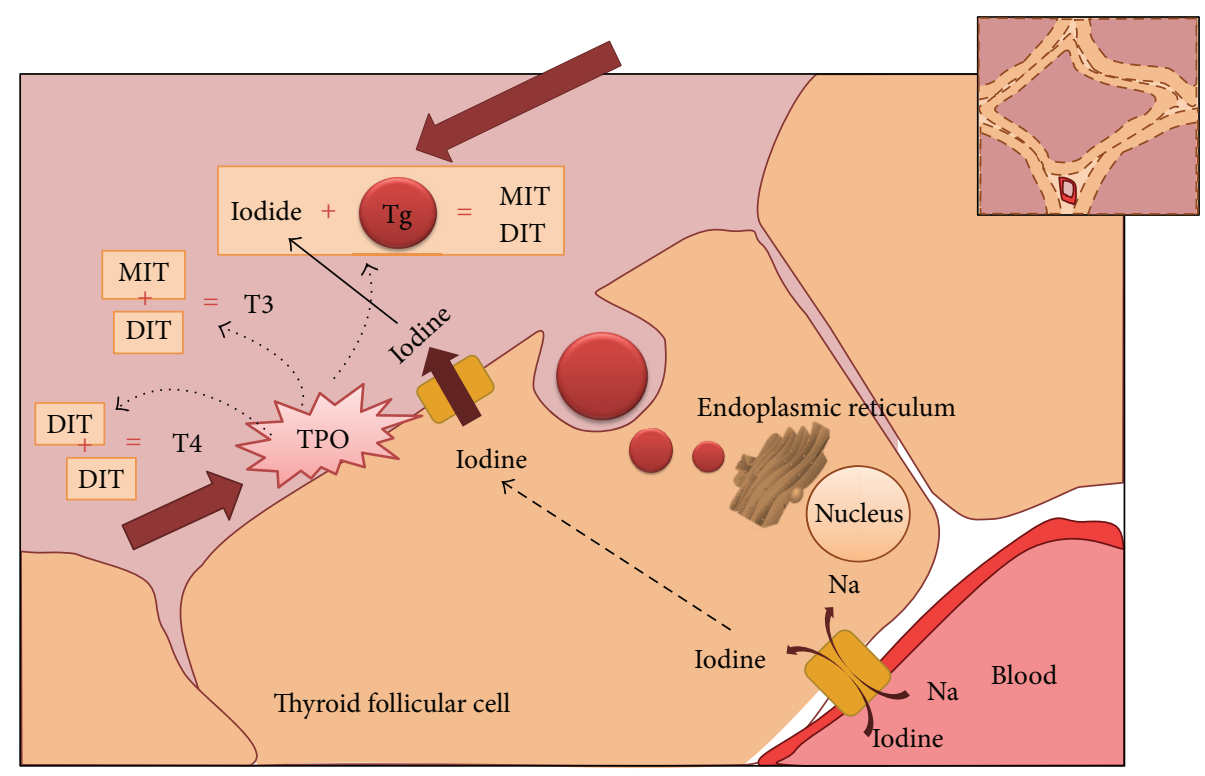

FIGURE 1: Thyroglobulin and thyroid peroxidase in thyroid hormone biosynthesis. The essentiality of thyroglobulin and thyroid peroxidase is shown in this simplified diagram of thyroid hormone biosynthesis. Thyroglobulin acts as the skeleton in thyroid hormone synthesis. It is synthesized and glycosylated in the rough endoplasmic reticulum, and is exocytosed through the apical membrane. Thyroid peroxidase acts in three parts (a) it oxidizes iodine, (b) organifies iodide to the tyrosine residues to the thyroglobulin forming monoiodotyrosine and diiodotyrosine (c) Couples monoiodotyrosine and di-iodotyrosine to either T4 or T3 (TPO: thyroid peroxidase, Tg: thyroglobulin, MIT: monoiodotyrosine, DIT: di-iodotyrosine, T4: thyroxine, and T3: triiodothyronine).

in thyroid hormone synthesis is emphasized by mutations in the Tg gene, which may lead to various degrees of congenital hypothyroidism [16]. Thyrotropin (TSH) stimulates the expression of $\mathrm{Tg}$ via the TSH receptor, but its expression is not TSH dependent, since it can be maintained by IGF-1 and other growth factors [17].

The TPO gene on chromosome 2 p25 is also regulated by $\mathrm{TSH}$, but in this case it is much more transcriptionally TSH dependent than $\mathrm{Tg}$ with expression lost in the absence of TSH. TPO is a membrane associated protein of approximately $107 \mathrm{kDa}$ and expressed mostly on the apical surface of the thyrocyte. It is thyroid peroxidase which catalyzes the coupling of two molecules of DIT or one of DIT and MIT for the formation of T4 and T3, which is then stored in the colloid as part of the Tg molecule [14].

2.3. Characteristics of TPO-Ab and Tg-Ab. Antibodies are Bcell produced Y-shaped proteins that are essential for the identification and neutralization of bacteria and viruses [19]. Autoantibodies which are pathologic to self molecules have been the sine qua non of autoimmune disease, including the autoimmune thyroiditides [20]. In addition, natural autoantibodies present in all of us and which are present without exposure to a foreign antigen [21] may also have a functional role in the immune response [22]. The autoimmune responses to $\mathrm{Tg}$ and TPO are polyclonal and the result, therefore, of multiple gene involvement. The autoantibodies to $\mathrm{Tg}$ and TPO are predominantly of the immunoglobulin (Ig) G class $[18,23]$ although lower levels of IgA class Tg-Ab and TPO-Ab can also be found in patients with AITD [24, 25] and they can be found in all IgG subclasses [26]. Using a variety of
TABLE 1: Tg-Ab and TPO-Ab as clinical markers.

\begin{tabular}{ll}
\hline & Tg-Ab and TPO-Ab as clinical Markers \\
\hline Positivity & $\begin{array}{l}\text { More likely to be TPO-Ab than Tg-Ab if serum } \\
\text { positive for only one autoantibody }\end{array}$ \\
\hline Prevalence & $\begin{array}{l}\text { TPO-Ab are more prevalent than Tg-Ab in the } \\
\text { community, and in Grave's disease }\end{array}$ \\
\hline \multirow{2}{*}{ Titers } & $\begin{array}{l}\text { Tg-Ab and TPO-Ab fluctuate in parallel, decreasing } \\
\text { after antithyroid drugs, increase transiently after I } \\
\text { therapy, decrease during pregnancy, increase } \\
\text { post-partum, and are induced/enhanced by } \\
\text { interferon- } \alpha\end{array}$ \\
\hline Predictors & $\begin{array}{l}\text { TPO Ab Better than Tg-Ab in predicting post-partum } \\
\text { thyroid dysfunction }\end{array}$ \\
\hline Disease & Tg-Ab alone not significantly associated with disease
\end{tabular}

The comparison of thyroglobulin and TPO antibody as used as clinical markers. Adapted from McLachlan and Rapoport 2004 [18].

monoclonal TPO-Ab Fab preparations, it has been noted that serum TPO-Abs interact with a restricted region on TPO, termed the immunodominant region, recognized by $>80 \%$ of individuals $[27,28]$. Although TPO-Ab and Tg-Abs are both markers of thyroid autoimmunity, it has been argued that TPO-Ab is more relevant in the prediction of thyroid dysfunction (Table 1) [18]. Whether TPO is a more important thyroid autoantigen than $\mathrm{Tg}$ is doubtful, since its gene is not associated with AITD [29], although there is evidence for inheritance of an IgG subclass pattern of expression [30]. Since both TPO and Tg can initiate thyroiditis in animal models, this suggests that both are potent autoantigens $[2,12]$. 


\section{Thyroid Autoantibodies in the Normal Population}

3.1. Epidemiology. In the original Whickham study in the United Kingdom, performed in the 1970s, it was estimated that the prevalence of $\mathrm{Tg}-\mathrm{Ab}$ was $2 \%$ in the sample of 2799 people, while TPO-Abs were present in $6.8 \%$ of the sample [31]. The frequency increased with age in females, but not in males and only $2.2 \%$ of males compared with $8 \%$ of females had TPO-Ab. The National Health and Nutrition Examination Survey (NHANES) data from the USA reviewed in 2002, examining 17,353 people, showed TPO-Ab in $13 \%$ and $\mathrm{Tg}-\mathrm{Ab}$ in $11.5 \%$ of the population using more sensitive assays. Similar to the findings in the Whickham study followup, there was an increase in thyroid autoantibodies with age in females. NHANES also showed that the prevalence of TPO-Ab and $\mathrm{Tg}-\mathrm{Ab}$ was higher in Caucasians, as compared to African Americans [32].

3.2. Regulation of the B-Cell: The Source of Autoantibodies. Bcells are lymphocytes that play a major role in the humoral immune response including immunoglobulin (Ig) secretion and antigen presentation. They are usually divided into two lineages. The first is the $\mathrm{B} 1$ lineage which produces polyreactive antibodies of the IgM class, often referred to as natural antibodies that do not undergo hypermutation of their variable genes. The second is the B2 lineage which is capable of generating a variety of antibodies of different Ig classes and subclasses [33]. The genetic recombination of $\mathrm{V}, \mathrm{D}$, and J region segments of the immunoglobulin heavy chains, followed by similar recombination in the light chain of the $\mathrm{V}$ and $\mathrm{J}$ segments happens prior to antigen recognition. Antibody genes undergo these DNA rearrangements during B-cell maturation, allowing the production of millions of different antibody molecules. This generates a remarkable diversity of antibodies but also introduces the chance of self-reactivity [34]. This self-reactivity is balanced by multiple mechanisms, including receptor revision, B-cell clonal deletion, and anergy [35]. After encounter with antigen, the B-cells differentiate into memory B-cells and plasma cells that can secrete all heavy chain classes [36].

B-cell activating factor (BAFF), a member of the tumor necrosis factor receptor (TNF-R/TNF) superfamily, is expressed on the B-cell surface, and a related molecule, a proliferation-inducing ligand (APRIL), is also effective regulator of immunity [37]. BAFF appears to have a role in the induction of B-cell maturation, class switch recombination of naïve $\operatorname{IgM}+\operatorname{IgD}+\mathrm{B}$-cells, and is a costimulator of $\mathrm{T}$ cells [37]. APRIL is similarly involved in class switch recombination and seems to have a costimulatory effect on B-cells [38]. Serum BAFF concentrations have been noted to be increased in autoimmune disease [39] Animal studies with BAFF and APRIL inhibitors have shown a reduction in hyperthyroxinemia and TSH receptor antibodies in a murine model of Grave's disease [40]. In humans with Grave's disease, the BAFF levels significantly correlated with $\mathrm{Tg}-\mathrm{Ab}$ but not with TPO-Ab nor TSHR-Ab [41].

3.3. Other Factors Affecting Immunoglobulin Secretion. Murine studies have shown that $\mathrm{T}$ cells can induce the secretion of immunoglobulins [42] IL-4 a cytokine produced by Th cells affects class switching and may suppress immunoglobulin secretion [43]. TGF- $\beta$, secreted primarily by activated $\mathrm{T}$ cells, may also have a role in class switch recombination [44].

CD40 is a costimulatory protein that is found on many antigen presenting cells. The interaction of CD40 with CD40L on the $\mathrm{T}$ cell provides essential costimulatory signals to B-cells, allowing immunoglobulin class switching, and germinal cell formation [45]. B7 is another protein found in antigen presenting cells that is important in full activation of $\mathrm{T}$ cells, that may have a role in immunoglobulin secretion. When paired with CD28 in T cells, this may affect baseline limmunoglobulin levels and alter the relative proportions of immunoglobulin subclasses [46].

Transcription factors involved in regulation at the level of immunoglobulin-secreting plasma cells include BLIMP1 (Blymphocyte-induced maturation protein 1 ) and XBP-1 (X-box binding protein 1). BLIMP1 regulates the secretion through decreased transcription of immunoglobulin heavy chain and light chain genes and also influences the J chain. XBP1 induces gene expression leading to increase in the size of the B-cell, the mitochondria, and the size of the endoplasmic reticulum, as well as having direct actions on the endoplasmic reticulum itself [47].

3.4. Regulation of Thyroid Autoantibody Secretion. In autoimmune thyroid disease, it appears that Tg-Ab and TPOAbs are more a response to thyroid inflammation than the actual cause as evidenced by their polyclonality and their failure to induce disease when transferred to animal models. However, it seems that at least in animal studies in both obese chicken [49] and NOD mice [50] thyroid antibodies develop spontaneously with no clear precipitator. It is still unclear what first induces thyroid antibody production in humans, but a few important observations have been made. For example, thyroid antibodies are less common in children. Studies performed in Indian and Greek peripubertal boys and girls $[51,52]$ have noted TPO-Ab positivity at only $\sim 4.5 \%$, with antibodies most prevalent in postpubertal girls [52]. In the geriatric population, it is known that autoantibodies tend to increase with age [53]. However, one small cross-sectional study comparing female centenerians with younger women noted the reduced occurrence of $\mathrm{Tg}-\mathrm{Ab}$ and $\mathrm{TPO}-\mathrm{Ab}$ in the centenerians [54] so it is possible that with extreme age there is a loss of autoantibody production or that the survivors have less evidence of autoimmune responses.

Few longitudinal studies exist in the population as with regards to conversion to thyroid antibody positivity. Using the original Whickham cohort, a twenty-year followup showed that $21 \%$ of women (at the time, 55-65 yrs) had developed antithyroid antibodies, at an age range corresponding to the time of menopause [27] and the same cohort showed that individuals who had been thyroid antibody positive originally were noted to have developed increased titers as they grew older [55].

Environmental factors may induce or suppress the development of autoantibodies (Table 2). The Hygiene Hypothesis has been supported by observations of increased thyroid 
TABLE 2: Regulation of thyroid antibodies in euthyroid and individuals with active thyroid disease.

\begin{tabular}{|c|c|c|}
\hline & Downregulated & Upregulated \\
\hline $\begin{array}{l}\text { Euthyroid } \\
\text { individuals }\end{array}$ & $\begin{array}{l}\text { (i) Extremes of ages } \\
\text { (ii) Pregnancy }\end{array}$ & $\begin{array}{l}\text { (i) Smoking discontinuation } \\
\text { (ii) Improvement in immune } \\
\text { collapse in HIV } \\
\text { (iii) Hep C treatment with } \\
\text { interferon } \\
\text { (iv) Nuclear fallout } \\
\text { (v) Iodine supplementation } \\
\text { (vi) Amiodarone, and iodine } \\
\text { containing drugs }\end{array}$ \\
\hline
\end{tabular}

\begin{tabular}{lll}
\hline & \multicolumn{3}{c}{ (i) Pregnancy } & \\
(ii) Radioiodine, after & (i) Postpartum \\
With thyroid & 1 year & (ii) Postradioiodine \\
disease & (iii) Antithyroid & treatment \\
& drugs & \\
& (iii) Selenium & \\
\hline
\end{tabular}

The table summarizes some of the various agents/events that may downregulate or upregulate thyroid autoantibodies (both TPO and Tg-Ab) in both euthyroid individuals and those with active thyroid disease. Abstracted from [35-47, 49-55].

antibodies in more affluent towns [56] suggesting that wider exposure to infection may reduce autoimmunity. A study in Amsterdam involving euthyroid relatives of AITD patients without antibodies to $\mathrm{Tg}$ or TPO noted an increase in seroconversion on discontinuation of smoking [57]. Studies comparing appropriate age and sex matched adolescents 1315 years after the Chernobyl nuclear accident in 1986 versus areas without exposure have shown a TPO-Ab and Tg-Ab prevalence of $8.5 \%$. Taken individually, TPO-Abs were more prevalent in exposed areas, while $\mathrm{Tg}$-Abs did not show a significant difference. It is interesting to note that combined $\mathrm{TPO}-\mathrm{Ab}$ and $\mathrm{Tg}-\mathrm{Ab}$ prevalence was much less [58] compared to studies performed earlier which showed a prevalence of 19.5\% (6-8 years after event) [59]. There was a rise after exposure, and progressive attenuation which is similar to the effects noted after radioiodine therapy in Grave's disease, as will be discussed later [58]. Thyroid autoimmunity and radioiodine did not have a dose-response relationship in a study on Hiroshima and Nagasaki Atomic bomb survivors 60 years after the event [60].

Iodine and iodine containing drugs such as amiodarone contribute to increases in thyroid autoantibodies as shown in many studies [61]. In Denmark, comparing two appropriately matched cross-sectional groups with and without iodine supplementation showed a marked increase in thyroid antibodies with iodine supplementation probably secondary to the increased iodination of thyroglobulin which enhances its immunoreactivity [62].

Improvement from immune collapse in patients with HIV may induce the appearance of thyroid autoantibodies and AITD and treatment of hepatitis $c$ with interferon alpha has had similar effects likely secondary to a direct influence on the thyroid cell [63].

In patients with Hashimoto's disease, the level of autoantibodies is affected by Selenium intake. Selenium deficiency seems to affect both the rate of thyroid cell necrosis [64] and immune function [65]. In a randomized, prospective blinded study in chronic autoimmune thyroiditis patients, selenium supplementation decreased TPO-Ab but not Tg-Ab [66].

In Grave's Disease a randomized prospective study compared TSHR-Ab in medical therapy, surgical therapy, and radioiodine therapy and showed a progressive decrease in titers in both medical and surgical therapy with gradual disappearance in 18 months in $70-80 \%$ of the patients. Radioiodine therapy induced a 1-year worsening of autoimmunity, while medical therapy showed a rebound after discontinuation of medications $[67,68]$. Tg-Ab and TPO-Ab were also increased after radioiodine treatment [69]. It has been previously theorized that this is partly due to the temporary increase in available autoantigens for the immune system [70], and an alternate theory is the direct effect of radioiodine on the immune system, especially on the suppressor T Cells $[69,71]$.

3.5. Changes in Pregnancy. Pregnant patients screened during the first trimester of pregnancy have an increased prevalence of thyroid autoantibodies (up to 20\%) reflective of the greater prevalence in this age group rather than secondary to the pregnancy itself $[48,72]$. In fact the physiologic changes surrounding pregnancy include changes allowing an immunotolerant environment for the nonself fetus, and this results in a decline in autoantibodies. So in pregnancy there is a marked fall in both TPO-Ab and Tg-Ab levels followed by an increase in the postpartum (Figure 2) [48, 73]. It is now clear that many factors may have a role in creating this immunotolerant environment.

3.5.1. The MHC. All autoimmune diseases have shown a genetic association with the HLA gene locus as manifested by the prevalence of certain HLA alleles in the patient populations [74]. For example, Graves' disease has been widely associated with HLA-DR3 in Caucasians and further investigation has suggested that it is residue 74 (Arginine) in the molecule which is the major influence [75]. The fetomaternal interface, which includes the villous trophoblasts and syncytiotrophoblast microparticles, avoid allogeneic responses because they lack HLA class I and class II proteins and only express other MHC molecules such as HLA-S, -E, -F, and HLA-G [76] which are thought to confer resistance to NK cells [77].

3.5.2. T Lymphocytes. Animal studies have clearly demonstrated the important role of $\mathrm{T}$ cells in the context of pregnancy and tolerance. They function in an antigen-specific manner to limit maternal immune responses to the fetus [78]. Although studies of CD4+ T cells in human pregnancy have shown very modest changes in absolute numbers [79], the Th1/Th2 ratio has been proposed to indicate a successful pregnancy as a Th2 phenomenon, with the Th 2 chemokines downregulating the Th1 response [80]. However, this Th1/Th2 dichotomy was not able to explain the multitude of immune responses in pregnancy among them is the fact that some Th1 cytokines are necessary in some aspects of pregnancy [81] 


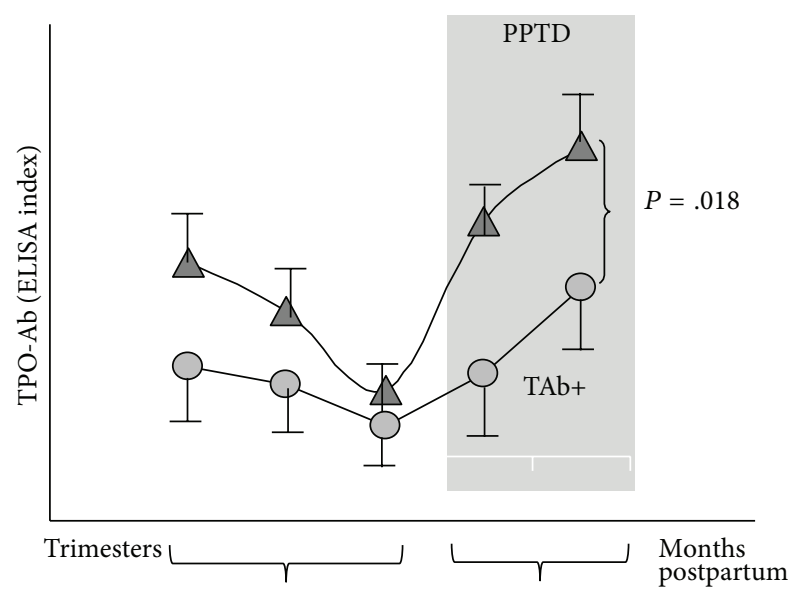

FIgUre 2: Thyroid antibody levels throughout pregnancy. There is a fall in thyroid autoantibodies reaching its nadir in the third trimester, before rebounding postpartum, in what is clinically seen as postpartum thyroid disease (PPTD: postpartum thyroid disease). Reproduced from [48].

and it did not explain the suppression of autoantibodies, including thyroid autoantibodies. We now know that the $\mathrm{CD} 4+\mathrm{CD} 25+$ FoxP3+ regulatory $\mathrm{T}$ cells are the most potent and widespread lineage of immune cells that are capable of regulating immune function [82]. Treg cells may proliferate peripherally after encountering foreign antigens (such as fetal antigens) and migrate towards the feto-maternal interface generating a tolerant environment characterized by cytokines such as TGF- $\beta$, Leukemia Inhibitory Factor (LIF), and HO1 which are proposed to protect pregnancy [83]. Hence, increases in Treg cells during pregnancy have been well documented and clearly are major contributors to the dampening of autoimmune responses in pregnancy. It is also likely that deficiency in their function or proliferative responsiveness may endanger a pregnancy [84].

3.5.3. B-Cells. B-cells are not only capable of antibody secretion but are also potent antigen presenting cells interacting with the T-cell receptors [86]. However, there appear to be no significant changes in the quantity of B cells in the circulation during normal human pregnancy yet one unifying characteristic is the fall in autoantibody titers (Figure 2) most likely secondary to the increase in Treg cells. However, estrogen has also been shown to deliver a negative signal towards Bcell function in pregnancy [87], and this effect is lost in the postpartum. Newly described B-regulatory cells discussed above have also been shown to modulate the immune response and inflammation [88] but their role in pregnancy still remains to be elucidated.

\section{Influence of Thyroid Antibodies on Reproduction}

4.1. Fertility and Miscarriage. The absolute inability to conceive after approximately 1 year of regular intercourse without contraception is defined subjectively as infertility [89]. A pooled review of the multiple studies involving autoimmune thyroid disease (AITD) in women with infertility compared to controls showed an overall relative risk of infertility of 2.1 $(P<0.0001)$. However, this should be interpreted cautiously as these studies were retrospective reviews with different causes of infertility and different assays for detecting thyroid antibodies [90]. Infertility may be due to the hormonal changes associated with AITD or to problems with implantation of the embryo [91], reflected more clearly in established pregnancies by early miscarriages. The studies of StagnaroGreen [48] in New York in 1990 and confirmed by Glinoer et al. [92] in Belgium and in multiple subsequent studies have demonstrated increases in the miscarriage rate in women who are thyroid autoantibody positive and such women are also more likely to deliver early [93]. A meta-analysis ascertaining this relationship showed an odds ratio (OR) of 2.73 (95\% CI 2.20-3.40) in 8 case controls and 10-longitudinal studies (Figure 3) [94].

As mentioned earlier, a number of etiologies have been hypothesized as the cause of the relationship between spontaneous termination of pregnancy and autoimmune thyroid antibodies. These include (1) the existence of a subtle degree of hypothyroidism, (2) thyroid antibodies reflecting an autoimmune imbalance in the pregnant female, (3) thyroid autoantibodies acting directly on the placenta or the fertilized ovum causing rejection, or (4) women with thyroid autoantibodies becoming pregnant at an older age, hence with an increased risk. Mild thyroid failure has been implicated in thyroid antibody positive women who have miscarriages and are euthyroid as judged by routine thyroid function tests, since higher levels of TSH within the normal range have been noted in meta-analysis studies [94]. One study showed a marked reduction in miscarriages when thyroid antibody women were treated with thyroxine [95].

4.2. Endometriosis. Of interest, AITD may also occur in patients with endometriosis which has a frequent association with infertility [96]. In the study of Poppe et al., involving 197 women with a female cause of infertility, they found $11 \%$ were attributed to endometriosis. Of these $11 \%$, $29 \%$ were TPO $\mathrm{Ab}+$, which was a significantly higher prevalence compared to controls [97]. Endometriosis has also been associated with immunological changes, including possible endometrial autoantibodies [96] and deposition of complement, cytotoxic effects on the endometrium, and declining levels or functional defects in natural killer (NK) cells [98]. Such NK cell dysregulation may activate Graves' disease or Hashimoto's thyroiditis [99].

4.3. Influence of Thyroid Antibodies on IVF Failure. It was Geva et al. that first described the possible correlation of in vitro fertilization (IVF) and thyroid antibodies in a study examining organ-specific autoimmune antibodies arguing for its possible role in predicting poor success for IVF, in such patients [100]. The pregnancy rate in women with thyroid antibodies, in their study, was only $13.6 \%$. In a prospective cohort study, 234 women were screened for TPO-Ab, serum TSH, and Free T4 prior to the first cycle of IVF, and there was a $50 \%$ miscarriage rate in females with thyroid antibody positivity but only a $23 \%$ rate of loss in those who did 


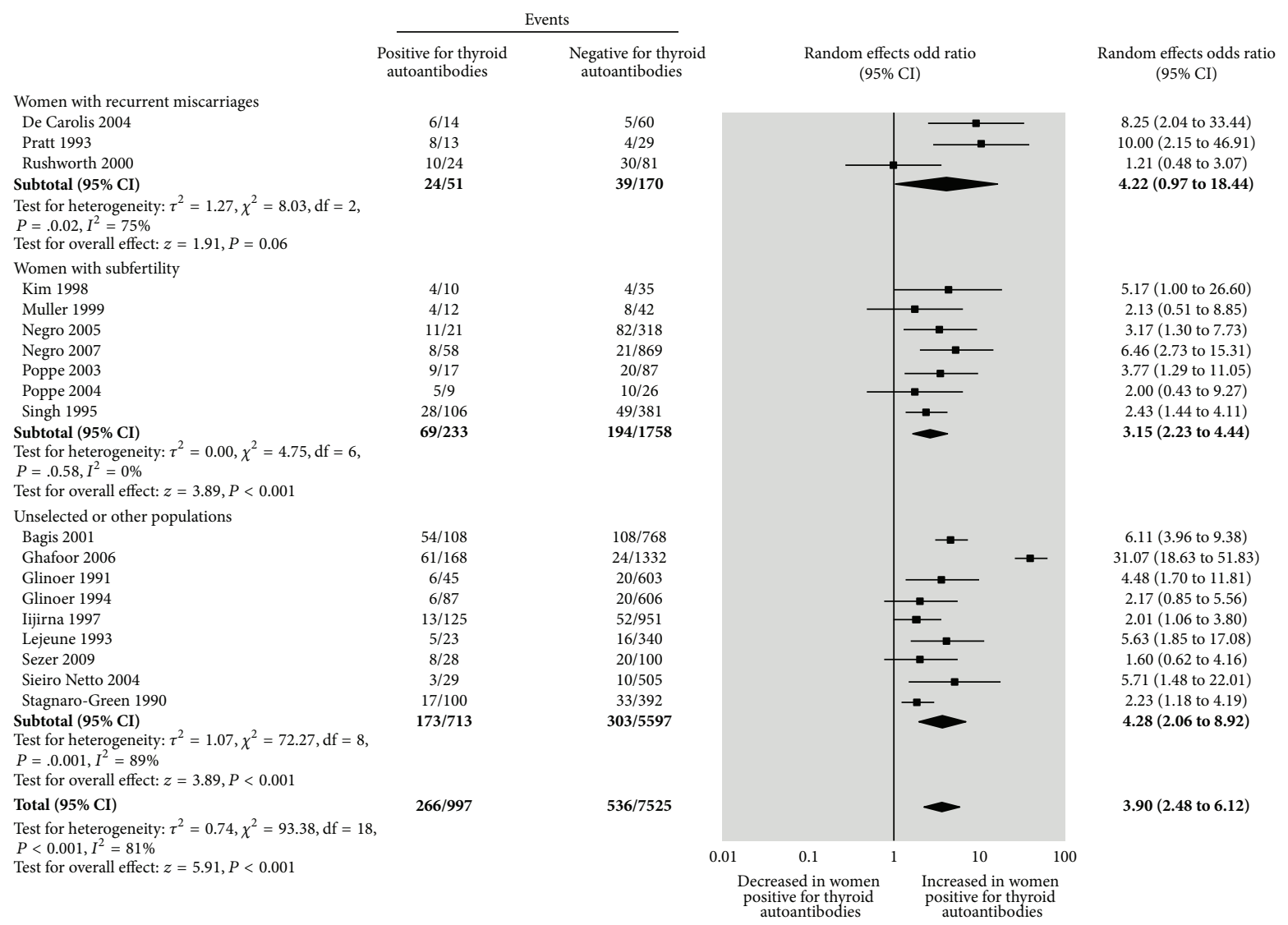

FIGURE 3: Relationship between thyroid antibodies and Miscarriages. The association of thyroid autoantibodies and miscarriages in multiple cohort studies is shown in meta-analysis by Thangaratinam et al. 2011 [85]. There is an increased prevalence of women positive for thyroid autoantibodies in individuals with subfertility and with recurrent miscarriages.

not [101]. The hypotheses that have been suggested for this relationship are similar to those of miscarriage in normal pregnancy discussed earlier. However, one study of the use of levothyroxine in IVF in euthyroid women did not show any differences in the frequency of miscarriages compared to untreated controls suggesting a different pathophysiology [102], but a recent meta-analysis of 220 patients in 3 randomized control trials showed improvement in the rate of delivery and embryo implantation in LT4 supplemented patients versus placebo treated patients and a decreased rate of miscarriage [103].

\section{Thyroid Failure and Thyroid Autoantibodies}

5.1. Definitions. Hashimoto's thyroiditis is often defined as the simple presence of serum thyroid autoantibodies which, pathologically, correlate well with an intrathyroidal lymphocytic infiltrate [104]. It requires more than $75 \%$ of thyroid function to be compromised before thyroid failure is reflected in changes in thyroid function testing and so newly diagnosed patients with thyroid failure often have had the disease for many years. Hence, efforts to design studies to discover precipitating events have been difficult in gathering a population to study because of the time lag between the development of actual thyroid pathology and biochemical or clinical symptomatology.

5.2. Prevalence in Pregnancy. Hypothyroidism, defined by an increase in TSH, is found in 4.6-5\% of all pregnancies [105]. Hashimoto's thyroiditis, even with the varying definitions, is the most common cause of such hypothyroidism in pregnancy $[106,107]$. Hence, there are a large number of children who have been exposed to thyroid autoantibodies in utero and who may have been hypothyroid during development $[108,109]$.

5.3. Outcomes in Maternal Hypothyroxinemia. It was Man (1972) who initially described how maternal hypothyroxinemia may have profound effects on the intellect of the children without the presence of classic cretinism [111]. Since then, multiple studies have supported the association between overt maternal hypothyroidism and abnormal development of the neural system in the offspring. A large retrospective study involving $\sim 25,000$ pregnant women and their children tested at $\sim 8$ years of age, using multiple developmental tests including IQ, showed that the children of untreated hypothyroid mothers had IQ levels more than 1 standard deviation below those children born to control mothers [108]. 
More recent studies have confirmed this effect-with intellectual and motor development differing even when measured as soon as 25-30 months [112]. The evaluation of offspring from more mildly affected mothers who were not diagnosed with Hashimoto's thyroiditis preconception and went through pregnancy without treatment has showed similar intellectual disparities as seen in the study by Haddow et al. [108]. In a prospective, three-year, study by Pop et al. children of mothers with low Ffree T4, but TSH within their normal range, had a delay in the development of mental and motor skills at ages of 1 and 2 years. In the same study, children whose mothers had their T4 increased in the latter part of pregnancy did not show any delay in their child's development [113]. However, a recent interventional trial of mildly affected women, where the mean TSH of affected mothers was only $3.5 \mathrm{uU} / \mathrm{mL}$, failed to show any difference in developmental testing and IQ between the children of treated and control mothers at 3.5 years of age [105]. To date, therefore, the timing, level, and duration of thyroid failure needed to affect intellectual development in the long-term remain unclear.

5.4. Perinatal and Obstetric Outcomes with Thyroid Antibodies. The possible effect of TPO antibodies in perinatal and obstetric outcomes was studied in $\sim 17,000$ euthyroid thyroid peroxidase antibody positive and negative women which revealed a fourfold increase in the incidence of placental abruption [114]. A meta-analysis of 11 studies showed that the overall combined relative risk of preterm delivery for pregnant women with TPO-Ab was also significantly increased $(\mathrm{RR}=1.9895 \% \mathrm{CI} 1.29-3.04 P=0.002)$ (excluding women with any thyroid dysfunction) [115].

\subsection{Thyroid Antibodies and Cognitive Development. TPO and} $\mathrm{Tg}$ antibodies are noted to be prevalent in up to $20 \%$ of the pregnant population and cross the placenta [107]. Despite the wide interest in the concept of Hashimoto's encephalitis [116], there have been few studies examining the influence of thyroid autoantibodies themselves and cognitive development in the offspring. While Haddow's study did not show any correlation between cognitive outcomes and maternal TPO antibodies [108], another study has suggested differences in the offspring with regards to perceptual performance on general, cognitive, and motor scales [109]. It is unclear whether TPO antibodies are just markers for thyroid function, rather than having an effect per se' on neonatal development, but to date there is no biological evidence to suggest a mechanism for an influence of thyroid autoantibodies to $\mathrm{Tg}$ and TPO on the intellectual development of the fetus.

5.6. Postpartum Autoimmune Thyroiditis. The ATA Guidelines have defined postpartum thyroiditis (PPT) as the occurrence of thyroid dysfunction in the first postpartum year in women who were euthyroid prior to pregnancy [118]. postpartum thyroid dysfunction is a more encompassing term which defines thyroid dysfunction ranging from postpartum thyroiditis to postpartum Grave's Disease. In those women who are TPO antibody positive, there is a noticeable rise in levels postpartum [119]. In addition, thyroid autoantibodies serve as the principal clinical predictor of the development of postpartum thyroiditis (PPT) in the 4-12 months postpartum (Table 3) [117]. The measurement of thyroglobulin antibodies has proven to be clinically less rewarding in postpartum thyroiditis.

This form of thyroid dysfunction resembles Hashimoto's thyroiditis clinically and biochemically except for the fact that it tends to be transient-usually lasting just a few months and passing from a destructive phase with a suppressed TSH level to a hypothyroid phase with an increased TSH level before normal thyroid function returns. A meta-analysis of 15 studies of PPT showed the prevalence rate to be $9.0-11.7 \%$, with higher prevalence in high risk groups such as women with type 1 diabetes mellitus, a family history of thyroid disease, or a prior history of thyroid disease. There may also be geographical differences secondary to genetic or environmental modulation [120]. While $50 \%$ of TPO-Ab positive women will develop PPTD, it can also spontaneously arise in the absence of TPO antibodies during pregnancy [121]. Hence, the use of TPO-Ab in screening populations may have utility. In a study of 410 patients. TPO-Ab screening in early pregnancy had a sensitivity of $100 \%$, with a specificity of $41 \%$ and a positive predictive value of $48 \%$. This means that almost half of the individuals who screened positive for TPOAb eventually developed postpartum thyroiditis [117].

PPT may become permanent in the post partum or portend thyroid failure in later years [117]. A large prospective study from Southern Italy, an area of mild deficiency, showed an incidence of PPT to be $3.9 \%$, with $50 \%$ remaining hypothyroid after 1 year [122]. Smaller studies with a mean followup of around 3-12 years have reported varying levels of permanent hypothyroidism, ranging from $15-46 \%$. In a longitudinal study for 12 years of 71 patients with PPTD, 27 or $38 \%$ of the women developed permanent hypothyroidism [123].

\section{Autoantibodies to the TSH Receptor}

The thyrotropin receptor (TSHR) is one of the primary antigens in autoimmune thyroid disease, being targeted by antigen-specific T cells and autoantibodies [125]. The TSH receptor is a seven transmembrane G-protein-coupled glycoprotein. It is the largest of the glycoprotein hormone receptors and is similar in structure to the luteinizing hormone and follicle stimulating hormone receptors (Figure 4). [126]. The TSHR consists of a large ectodomain made up of leucinerich repeat sequences, which is the principal antigenic region, and a transmembrane domain and a linking structure called the hinge region [124]. The TSHR signals via all of the Gprotein pathways but induces primarily both the PKA-cAMP and PKC-phospholipase C (Phosphoinositide 3-kinase-AKT$\mathrm{PKC)}$ transduction systems [127].

\section{Discovery of TSH Receptor Autoantibodies (TSHR-Abs)}

TSHR-Abs were initially described by Adams and Purvis in the 1950s [128] as a long acting thyroid stimulator (LATS) in the sera of patients with severe Grave's disease. They were 
TABLE 3: Sensitivity, specificity, and positive predictive values of thyroid autoantibodies when sampling done at the different times in pregnancy and post-partum adapted from Premawardhana et al. The positive predictive value of thyroid antibodies in predictive post-partum thyroid disease [117].

\begin{tabular}{|c|c|c|c|c|c|c|}
\hline Investigator & Antibody & $\begin{array}{l}\text { Ab-positive subjects } \\
\text { (Ab-negative subjects } \\
\text { with PPTD) }\end{array}$ & $\begin{array}{l}\text { Sampling time-(pp) } \\
\text { postpartum in months }\end{array}$ & Sensitivity & Specificity & PPV \\
\hline Jansson & Micro & $44(7)$ & $2-5$ & 0.77 & 0.95 & 0.52 \\
\hline Amino & Micro & $61(1)$ & 3 & 0.89 & 0.92 & 0.4 \\
\hline Lervang & Micro & $38(3)$ & 3 & 0.87 & 0.97 & 0.53 \\
\hline Vargas & Micro & $41^{*}$ & Delivery & 0.45 & 0.95 & 0.63 \\
\hline Vargas & Micro & $54(11)$ & $2-4$ & 0.76 & 0.91 & 0.65 \\
\hline Vargas & Micro & $69(8)$ & 5-7 & 0.86 & 0.9 & 0.68 \\
\hline Pop & Micro & $15(6)$ & Trimester 3 & 0.71 & 0.92 & 0.52 \\
\hline Kuijpens & TPO & $31(5)$ & Trimesters $1 / 3$ & 0.67 & 0.93 & 0.31 \\
\hline Kent & TPO & $55(31)$ & 6 & 0.64 & 0.95 & 0.64 \\
\hline Kent & Micro & $40(46)$ & 6 & 0.46 & 0.98 & 0.78 \\
\hline \multirow[t]{2}{*}{ Sakaihara } & Micro/Tg & $50(65)$ & Early pp-1 & 0.14 & 0.88 & 0.07 \\
\hline & & & Early pp-3 & 0.37 & 0.90 & 0.21 \\
\hline Solomon & Micro & $55^{*}$ & Delivery & & & 0.73 \\
\hline Nohr & TPO & $66^{*}$ & Trimester 1 & - & - & 0.55 \\
\hline \multirow[t]{2}{*}{ Premawardhana } & TPO & $308(0)$ & Early pregnancy & 1.00 & 0.62 & 0.48 \\
\hline & & & Early Postpartum & 1.00 & 0.41 & 0.48 \\
\hline
\end{tabular}

Sensitivity is defined as the number of true positives as a proportion of the sum of the number of true positives and false negatives. Specificity, defined as the number of true negatives as a proportion of the sum of the false positives and true negatives. Positive predictive value (PPV) is defined as the number of truepositives as a proportion of the sum of true and false positives.

${ }^{*}$ Unknown or not included.

revealed by differences between the long half life of LATS in guinea pigs compared to the shorter half life of TSH and their work laid the groundwork for our understanding of Grave's disease today [129, 130]. However, it took two decades until Smith and Hall provided the direct evidence that this stimulating IgG was in fact due to the existence of TSH receptor autoantibodies [131]. And it took another three decades to develop a human monoclonal thyroid stimulating autoantibody derived from lymphocytes of a patient with Grave's disease [132].

\section{The Three Types of TSHR Antibodies}

Since TSHR signal propagation is classically mediated through the G-protein effectors, G $\alpha$ s and $G \alpha \mathrm{q}$, these signaling pathways have been used to investigate TSHR-Abs in patients with AITD [133]. Using the generation of intracellular cAMP as the end point, three types of TSHR antibodies have been characterized (Figure 5). Stimulating TSHR-Abs are the classical LATS antibodies which increase cAMP levels via the TSHR. Blocking TSHR-Abs reduce or totally block the action of TSH increasing cAMP generation and may also be found in patients with Hashimoto's thyroiditis [134], and "neutral" TSHR-Abs which do not influence TSH action have no effect on TSH binding nor cAMP levels but which signal through the PKC pathway and can induce cell apoptosis [135]. TSHR-Abs have a number of common characteristics. The stimulating variety is mostly restricted to IgG subclass 1 ; they are present in low titers with specific B-cells in low frequency, but the antibody affinity tends to be high [136].

\section{Measuring TSHR-Abs}

In the absence of Graves' orbitopathy, the diagnosis of Graves' disease can be made by hyperthyroid function tests in the presence of TSHRAb. Alternatively, the diagnosis can be indirectly concluded with hyerthyroidi function tests in the presence of a diffuse thyroid gland (by sonography or scanning) and a normal or increased 24 hour radioiodine uptake. TSHR-Ab testing adds considerably to the clinical picture since it is helpful in monitoring the response to treatment and in predicting the course of the disease [137]. In pregnancy, as we will discuss further, it is especially helpful in predicting the risk of neonatal thyroid dysfunction [138].

Currently, the assays available to detect TSHR-Abs in patients with Grave's disease reach a sensitivity of $\sim 80 \%$ but with a specificity of $100 \%$ [139] TSHR-Abs are not found in any disease other than AITD. There are two clinically available methods for measuring TSHR-Abs. The simplest and most precise approach is the receptor assays. These measure the inhibition of labeled TSH or a labeled monoclonal TSHR-Ab binding to solubilized TSHRs. While such assays can be automated and are cheap to perform, they do not differentiate between stimulating or blocking TSHR-Abs. Of course, in clinical practice this is not an issue, since the patient is the bioassay. If the patient is hyperthyroid we do not need 


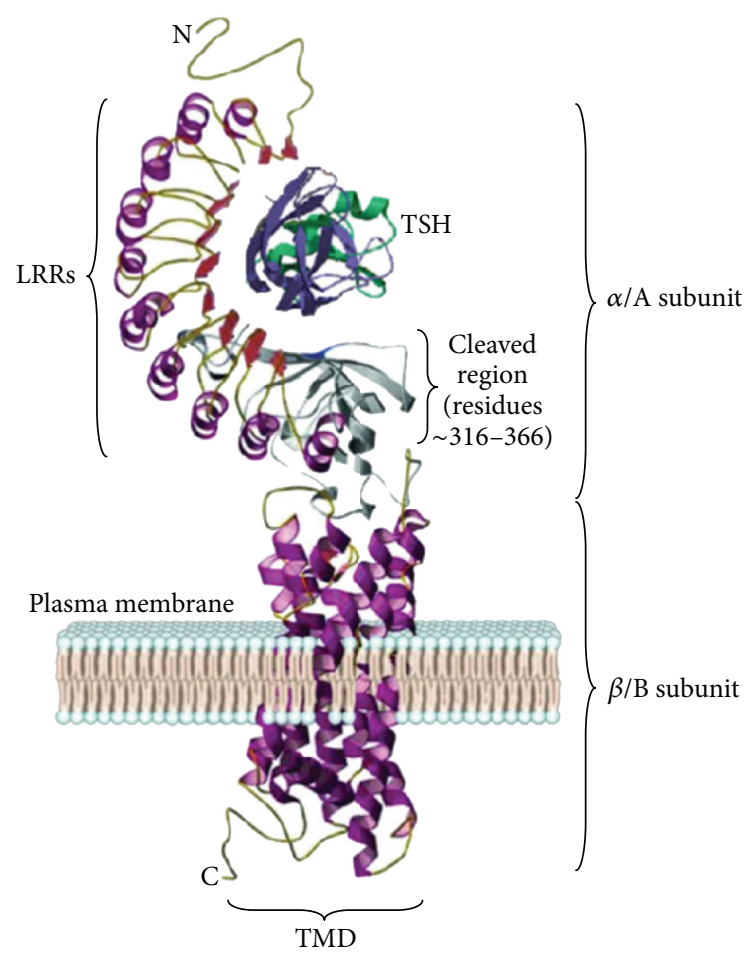

FIGURE 4: TSH Receptor Structure. The TSHR includes a large extracellular domain ( $\alpha$ or A subunit) that includes nine leucine-rich repeat (LRR) domains and transmembrane/intracellular domain (bor B subunit). Adapted from [110].

a laboratory test to tell us that the TSHR-Ab is primarily of the stimulating variety.

In pregnancy, when we are concerned with the thyroid status of the neonate, it can be helpful to know the biological action of any persistent TSHR-Abs and so biological assays are available commercially. These measure the stimulation or the inhibition of TSHR activity by measuring CAMP as the end point [140]. These assays are sensitive but are expensive and imprecise. The information gathered is clinically useful since either stimulation or inhibition of TSHR activity has different effects on the neonate.

\section{Stimulating TSHR-Abs and Pregnancy}

TSHR-Abs cross the placenta and can induce neonatal thyrotoxicosis. However, pregnancy usually suppresses Grave's disease. Although exacerbations early in pregnancy are sometimes observed [141] once the first trimester is passed the immune suppression of pregnancy sets in, the Treg cells increase their effectiveness, and the disease very often abates. The aggravation of thyrotoxicosis in the first part of pregnancy is probably secondary to the added effects of hCG which itself can cause gestational thyrotoxicosis [141-143]. In keeping with this scenario, TSHR-Abs reach their lowest point at the time of delivery $[144,145]$. Hence, the dose of antithyroid drugs is rapidly decreased during pregnancy so that by the 3rd trimester a third of patients are taking none at all $[145,146]$. This means that women have to be monitored for their TSHR-Ab status until they are negative.
Since many patients with Graves' disease have stimulating, blocking and neutral TSHR-Abs, their interplay during the immune suppression of pregnancy can be extremely complex. For example, blocking antibodies have been noted to increase during pregnancy suggesting this as an explanation for the consequent clinical remission of thyrotoxicosis [147]. However, as pregnancy suppresses humoral immunity, all types of TSHR-Ab should be depressed. While many studies have confirmed this, there remain contrary findings which may depend on a woman's individual immune response to the pregnancy [147-149].

\section{Postpartum Recurrence of Graves' Disease}

Titers of TSHR-Abs may increase in the post partum after the loss of the immune suppression of pregnancy. This tends to be seen most commonly from 4-12 months post partum and may lead to recurrence, or even the new onset, of Graves' disease. This occurs at the same time as women may alternatively develop post partum thyroiditis, which may also depress the serum TSH early in its pathology [119]. Hence, women with a suppressed TSH and all those with a history of Graves' disease need to be screened carefully in the post partum for the presence of TSHR-Abs [150]. There has been no correlation between the levels of TSHR-Abs before, or early, in pregnancy and the initiation of postpartum Grave's disease, once again indicating the importance of the women's own immune response to their pregnancy [151].

\section{Perinatal/Fetal Repercussions of TSHR-Abs}

Fetal hyperthyroidism is suspected in fetuses with heart rates $>160$ and intrauterine growth retardation [152]. This requires the presence of both maternal IgG in sufficient quantities and a thyroid that is mature enough to respond [153]. The fetal thyroid gland matures after about 7 weeks although functionally its capacity to concentrate iodide and synthesize T4 does not occur until around the 11th week [154]. And fetal hyperthyroidism does not clinically manifest until the latter part of pregnancy [145]. The ATA has recommended measurement of TSHR-Ab by 24-28 weeks for detection of high risk pregnancies, with three times the upper normal value as an indication for closer followup for the fetus. Serial ultrasounds are recommended, while cordocentesis has been used in very rare situations where the thyroid status of the fetus was unclear [118].

\section{Neonatal Repercussions of TSHR-Abs}

Transient neonatal hyperthyroidism caused by transplacental passage occurs rarely in the context of maternal Grave's disease and develops $<1 \%$ of the cases. Since the half life of IgG is $\sim 3$ weeks, then the neonatal dysfunction slowly recovers after this time. It is suspected in neonates presenting with tachycardia, hyperexcitability, and poor weight gain. [155]. Transplacental passage of TSHR-Abs [156] has been titrated to the development of neonatal hyperthyroidism to such a careful extent that the maternal level can be used as a predictor of neonatal dysfunction [157]. This is clinically 

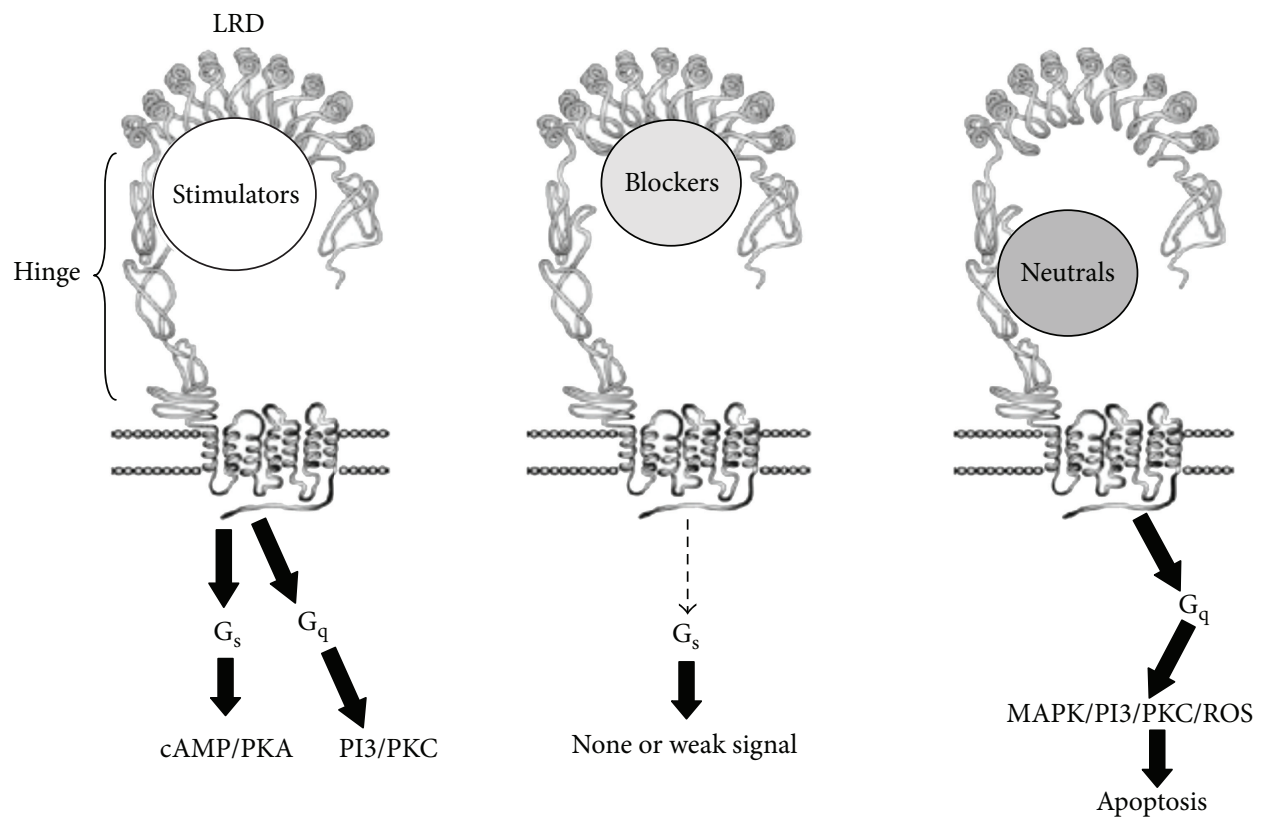

Figure 5: Types of TSH receptor antibodies. Three types of TSH receptor antibodies with their corresponding signal cascades. Adapted from [124].

important in those women whose maternal levels of TSHRAbs fail to diminish in the third trimester [145].

The transplacental passage of blocking TSHR-Abs [145] may, by contrast, cause transient hypothyroidism [158] in the neonate. There are cases of these transplacentally transferred antibodies causing delayed development of the infant's thyroid gland with a slow recovery of normal thyroid function in the post partum [159]. It has been estimated that $2 \%$ of congenital hypothyroidism may be caused by TSH receptor blocking antibodies [160].

\section{Thyroid Autoantibody Screening in Pregnancy}

The detection of thyroid antibodies before or early in pregnancy can predict the development of pregnancy loss, the need for thyroxine replacement therapy during pregnancy, and the onset of post partum thyroiditis [117]. Yet the latest American Thyroid Association guidelines [118] only comment on the lack of evidence needed to make any recommendations for the screening of thyroid autoantibodies in pregnancy. In addition, the Endocrine Society [161] still does not recommend screening for these antibodies in pregnancy. At least the guidelines do define the utility of measuring thyroid autoantibodies in some situations. For example, in postpartum depression, TPO Ab testing has been advocated. In euthyroid patients who are TSHR-Ab positive, all agree that close monitoring in pregnancy is needed.

\section{Conclusions}

Pregnancy complicates both the physiology of the thyroid cell and the immune response to thyroid antigens. Thyroid autoantibodies are involved in both these areas and are associated with major alterations in the course of pregnancy affecting the mother, the fetus, and the neonate. Thyroid antibodies can serve as useful clinical predictors of thyroid dysfunction, for example, TPO-Ab and post partum thyroiditis and TSHR-Abs and neonatal hyperthyroidism. But why humans are so susceptible to the development of thyroid autoantibodies remains uncertain.

\section{Acknowledgments}

This paper was supported in part by NIH Grants DK069713 and DK052464 and the VA Merit Award program.

\section{References}

[1] F. D. Balucan and T. F. Davies, "The immunology of autoimmune thyroid disease in pregnancy," Journal of the ASEAN Federation of Endocrine Societies, vol. 27, no. 1, pp. 18-26, 2012.

[2] L. Hektoen and K. Schulhof, "The precipitin reaction of thyroglobulin: specificness; presence of thyroglobulin in human thyroid veins; production by rabbit of precipitin for rabbit thyroglobulin; thyroglobulin in the foetal thyroid and in exophthalmic goiter," Proceedings of the National Academy of Sciences of the United States of America, vol. 11, no. 8, pp. 481-484, 1925.

[3] C. A. Owen Jr., "A review of auto-immunization in Hashimoto's disease," The Journal of Clinical Endocrinology \& Metabolism, vol. 18, no. 9, pp. 1015-1023, 1958.

[4] G. A. Fromm, E. F. Lascano, G. E. Bur, and D. Escalante, "Nonspecific chronic thyroiditis: Hashimoto's lymphoid struma; de Quervain's granulomatous struma; Riedel's fibrous struma," Revista de la Asociación Médica Argentina, vol. 67, no. 749-750, pp. 162-170, 1953.

[5] E. Witebsky, N. R. Rose, K. Terplan, J. R. Paine, and R. W. Egan, "Chronic thyroiditis and autoimmunization," The Journal of the 
American Medical Association, vol. 164, no. 13, pp. 1439-1447, 1957.

[6] P. N. Campbell, D. Doniach, R. V. Hudson, and I. M. Roitt, "Auto-antibodies in Hashimoto's disease (lymphadenoid goitre)," The Lancet, vol. 271, no. 6947, pp. 820-821, 1956.

[7] A. J. van Herle, R. P. Uller, N. I. Matthews, and J. Brown, "Radioimmunoassay for measurement of thyroglobulin in human serum," The Journal of Clinical Investigation, vol. 52, no. 6, pp. 1320-1327, 1973.

[8] N. R. Rose, R. Bonita, and C. L. Burek, "Iodine: an environmental trigger of thyroiditis," Autoimmunity Reviews, vol. 1, no. 1-2, pp. 97-103, 2002.

[9] S. A. R. van de Graaf, C. Ris-Stalpers, E. Pauws, F. M. Mendive, H. M. Targovnik, and J. J. M. de Vijlder, "Up to date with human thyroglobulin," Journal of Endocrinology, vol. 170, no. 2, pp. 307321, 2001.

[10] A. Hasham and Y. Tomer, "Genetic and epigenetic mechanisms in thyroid autoimmunity," Immunologic Research, vol. 54, no. 13, pp. 204-213, 2012.

[11] E. M. Jacobson and Y. Tomer, "The genetic basis of thyroid autoimmunity," Thyroid, vol. 17, no. 10, pp. 949-961, 2007.

[12] G. Belyavin and W. R. Trotter, "Investigations of thyroid antigens reacting with Hashimoto sera; evidence for an antigen other than thyroglobulin," The Lancet, vol. 1, no. 7074, pp. 648$652,1959$.

[13] L. Portmann, N. Hamada, G. Heinrich, and L. J. DeGroot, "Antithyroid peroxidase antibody in patients with autoimmune thyroid disease: possible identity with antimicrosomal antibody," The Journal of Clinical Endocrinology \& Metabolism, vol. 61, no. 5, pp. 1001-1003, 1985.

[14] D. Salvatore, T. Davies, M. Schlumberger, I. Hay, and P. Larsen, "Thyroid," in Williams Endocrinology, S. Melmed, K. S. Polonsky, P. Larsen, and H. Kronenberg, Eds., pp. 327-350, Elsevier, Philadelphia, Pa, USA, 12th edition, 2011.

[15] U. Feldt Rasmussen, "Serum thyroglobulin and thyroglobulin autoantibodies in thyroid diseases. Pathogenic and diagnostic aspects," Allergy, vol. 38, no. 6, pp. 369-387, 1983.

[16] H. M. Targovnik, C. E. Citterio, and C. M. Rivolta, "Thyroglobulin gene mutations in congenital hypothyroidism," Hormone Research in Paediatrics, vol. 75, no. 5, pp. 311-321, 2011.

[17] S. Clément, S. Refetoff, B. Robaye, J. E. Dumont, and S. Schurmans, "Low TSH requirement and goiter in transgenic mice overexpressing IGF-I and IGF-I receptor in the thyroid gland," Endocrinology, vol. 142, no. 12, pp. 5131-5139, 2001.

[18] S. M. McLachlan and B. Rapoport, "Why measure thyroglobulin autoantibodies rather than thyroid peroxidase autoantibodies?" Thyroid, vol. 14, no. 7, pp. 510-520, 2004.

[19] K. Murphy, P. Travers, M. Walport, and C. Janeway, Janeway's Immunobiology, Garland Science, New York, NY, USA, 8th edition, 2012.

[20] A. Davidson and B. Diamond, "Autoimmune diseases," The New England Journal of Medicine, vol. 345, no. 5, pp. 340-350, 2001.

[21] Y. Tomer and Y. Shoenfeld, "The significance of natural autoantibodies," Immunological Investigations, vol. 17, no. 5, pp. 389424, 1988.

[22] N. Gleicher, D. Barad, and A. Weghofer, "Functional autoantibodies, a new paradigm in autoimmunity?" Autoimmunity Reviews, vol. 7, no. 1, pp. 42-45, 2007.

[23] A. B. Parkes, S. M. McLachlan, P. Bird, and B. Rees Smith, "The distribution of microsomal and thyroglobulin antibody activity among the IgG subclasses," Clinical and Experimental Immunology, vol. 57, no. 1, pp. 239-243, 1984.
[24] M. F. Prummel, W. M. Wiersinga, B. Rapoport, and S. M. McLachlan, "IgA class thyroid peroxidase and thyroglobulin autoantibodies in Graves' disease: association with the male sex," Autoimmunity, vol. 16, no. 2, pp. 153-155, 1993.

[25] K. Beever, J. Bradbury, D. Phillips et al., "Highly sensitive assays of autoantibodies to thyroglobulin and to thyroid peroxidase," Clinical Chemistry, vol. 35, no. 9, pp. 1949-1954, 1989.

[26] P. Caturegli, R. C. Kuppers, S. Mariotti et al., "IgG subclass distribution of thyroglobulin antibodies in patients with thyroid disease," Clinical and Experimental Immunology, vol. 98, no. 3, pp. 464-469, 1994.

[27] G. D. Chazenbalk, S. Portolano, D. Russo, J. S. Hutchison, B. Rapoport, and S. McLachlan, "Human organ-specific autoimmune disease. Molecular cloning and expression of an autoantibody gene repertoire for a major autoantigen reveals an antigenic immunodominant region and restricted immunoglobulin gene usage in the target organ," The Journal of Clinical Investigation, vol. 92, no. 1, pp. 62-74, 1993.

[28] S. M. McLachlan and B. Rapoport, "Genetic and epitopic analysis of thyroid peroxidase (TPO) autoantibodies: markers of the human thyroid autoimmune response," Clinical and Experimental Immunology, vol. 101, no. 2, pp. 200-206, 1995.

[29] Y. Tomer, G. Barbesino, M. Keddache, D. A. Greenberg, and T. F. Davies, "Mapping of a major susceptibility locus for Graves' disease (GD-1) to chromosome 14q31," The Journal of Clinical Endocrinology \& Metabolism, vol. 82, no. 5, pp. 1645-1648, 1997.

[30] J. C. Jaume, J. Guo, D. L. Pauls et al., "Evidence for genetic transmission of thyroid peroxidase autoantibody epitopic 'fingerprints," The Journal of Clinical Endocrinology \& Metabolism, vol. 84, no. 4, pp. 1424-1431, 1999.

[31] W. M. G. Tunbridge, D. C. Evered, R. Hall et al., "The spectrum of thyroid disease in a community: the Whickham survey," Clinical Endocrinology, vol. 7, no. 6, pp. 481-493, 1977.

[32] J. G. Hollowell, N. W. Staehling, W. D. Flanders et al., "Serum TSH, T4, and thyroid antibodies in the United States population (1988 to 1994): National Health and Nutrition Examination Survey (NHANES III)," The Journal of Clinical Endocrinology \& Metabolism, vol. 87, no. 2, pp. 489-499, 2002.

[33] J. L. Browning, "B cells move to centre stage: novel opportunities for autoimmune disease treatment," Nature Reviews Drug Discovery, vol. 5, no. 7, pp. 564-576, 2006.

[34] M. J. Townsend, J. G. Monroe, and A. C. Chan, "B-cell targeted therapies in human autoimmune diseases: an updated perspective," Immunological Reviews, vol. 237, no. 1, pp. 264-283, 2010.

[35] H. von Boehmer and F. Melchers, "Checkpoints in lymphocyte development and autoimmune disease," Nature Immunology, vol. 11, no. 1, pp. 14-20, 2010.

[36] C. Janeway, Immunobiology: The Immune System in Health and Disease, Garland Science, New York, NY, USA, 6th edition, 2005.

[37] S. G. Tangye, V. L. Bryant, A. K. Cuss, and K. L. Good, "BAFF, APRIL and human B cell disorders," Seminars in Immunology, vol. 18, no. 5, pp. 305-317, 2006.

[38] F. C. Kimberley, J. P. Medema, and M. Hahne, "APRIL in B-cell malignancies and autoimmunity", Results and Problems in Cell Differentiation, vol. 49, pp. 161-182, 2009.

[39] J. O. Pers, C. Daridon, V. Devauchelle et al., "BAFF overexpression is associated with autoantibody production in autoimmune diseases," Annals of the New York Academy of Sciences, vol. 1050, pp. 34-39, 2005. 
[40] J. A. Gilbert, S. L. Kalled, J. Moorhead et al., "Treatment of autoimmune hyperthyroidism in a murine model of Graves' disease with tumor necrosis factor-family ligand inhibitors suggests a key role for B cell activating factor in disease pathology," Endocrinology, vol. 147, no. 10, pp. 4561-4568, 2006.

[41] G. Vannucchi, D. Covelli, N. Curro et al., "Serum BAFF concentrations in patients with Graves' disease and orbitopathy before and after immunosuppressive therapy," The Journal of Clinical Endocrinology \& Metabolism, vol. 97, pp. E755-E759, 2012.

[42] T. L. Stevens, A. Bossie, V. M. Sanders et al., "Regulation of antibody isotype secretion by subsets of antigen-specific helper T cells," Nature, vol. 334, no. 6179, pp. 255-258, 1988.

[43] C. Ninomiya and H. L. Spiegelberg, "IL-4 and transforming growth factor- $\beta$ suppress human immunoglobulin secretion in vitro by surface IgD- B cells," Clinical and Experimental Immunology, vol. 89, no. 2, pp. 261-268, 1992.

[44] J. Stavnezer and J. Kang, "The surprising discovery that TGF $\beta$ specifically induces the IgA class switch," The Journal of Immunology, vol. 182, no. 1, pp. 5-7, 2009.

[45] T. Kawabe, T. Naka, K. Yoshida et al., "The immune responses in CD40-deficient mice: impaired immunoglobulin class switching and germinal center formation," Immunity, vol. 1, no. 3, pp. $167-178,1994$.

[46] D. J. Lenschow, T. L. Walunas, and J. A. Bluestone, "CD28/B7 system of T cell costimulation," Annual Review of Immunology, vol. 14, pp. 233-258, 1996.

[47] M. Shapiro-Shelef and K. C. Calame, "Regulation of plasmacell development," Nature Reviews Immunology, vol. 5, no. 3, pp. 230-242, 2005.

[48] A. Stagnaro-Green, S. H. Roman, R. H. Cobin, E. El-Harazy, M. Alvarez-Marfany, and T. F. Davies, "Detection of at-risk pregnancy by means of highly sensitive assays for thyroid autoantibodies," The Journal of the American Medical Association, vol. 264, no. 11, pp. 1422-1425, 1990.

[49] G. Wick, R. S. Sundick, and B. Albini, "A review: the obese strain (OS) of chickens: an animal model with spontaneous autoimmune thyroiditis," Clinical Immunology and Immunopathology, vol. 3, no. 2, pp. 272-300, 1974.

[50] H. Braley-Mullen, G. C. Sharp, B. Medling, and H. Tang, "Spontaneous autoimmune thyroiditis in NOD.H-2h4 mice," Journal of Autoimmunity, vol. 12, no. 3, pp. 157-165, 1999.

[51] R. K. Marwaha, N. Tandon, A. K. Desai et al., "The evolution of thyroid function with puberty," Clinical Endocrinology, vol. 76, no. 6, pp. 899-904, 2012.

[52] I. Kaloumenou, G. Mastorakos, M. Alevizaki et al., "Thyroid autoimmunity in schoolchildren in an area with long-standing iodine sufficiency: correlation with gender, pubertal stage, and maternal thyroid autoimmunity," Thyroid, vol. 18, no. 7, pp. 747$754,2008$.

[53] Y. Tomer and Y. Shoenfeld, "Ageing and autoantibodies," Autoimmunity, vol. 1, no. 2, pp. 141-149, 1988.

[54] F. Magri, B. Muzzoni, L. Cravello et al., "Thyroid function in physiological aging and in centenarians: possible relationships with some nutritional markers," Metabolism, vol. 51, no. 1, pp. 105-109, 2002.

[55] W. M. G. Tunbridge, M. Brewis, J. M. French et al., "Natural history of autoimmune thyroiditis," British Medical Journal, vol. 282, no. 6260, pp. 258-262, 1981.

[56] T. F. Davies, "Infection and autoimmune thyroid disease," The Journal of Clinical Endocrinology \& Metabolism, vol. 93, no. 3, pp. 674-676, 2008.
[57] G. Effraimidis, J. G. P. Tijssen, and W. M. Wiersinga, "Discontinuation of smoking increases the risk for developing thyroid peroxidase antibodies and/or thyroglobulin antibodies: a prospective study," The Journal of Clinical Endocrinology \& Metabolism, vol. 94, no. 4, pp. 1324-1328, 2009.

[58] L. Agate, S. Mariotti, R. Elisei et al., “Thyroid autoantibodies and thyroid function in subjects exposed to chernobyl fallout during childhood: evidence for a transient radiation-induced elevation of serum thyroid antibodies without an increase in thyroid autoimmune disease," The Journal of Clinical Endocrinology \& Metabolism, vol. 93, no. 7, pp. 2729-2736, 2008.

[59] F. Pacini, T. Vorontsova, E. Molinaro et al., "Prevalence of thyroid autoantibodies in children and adolescents from Belarus exposed to the Chernobyl radioactive fallout," The Lancet, vol. 352, no. 9130, pp. 763-766, 1998.

[60] M. Imaizumi, T. Usa, T. Tominaga et al., "Radiation doseresponse relationships for thyroid nodules and autoimmune thyroid diseases in Hiroshima and Nagasaki atomic bomb survivors 55-58 years after radiation exposure," The Journal of the American Medical Association, vol. 295, no. 9, pp. 1011-1022, 2006.

[61] E. Martino, L. Bartalena, F. Bogazzi, and L. E. Braverman, "The effects of amiodarone on the thyroid," Endocrine Reviews, vol. 22, no. 2, pp. 240-254, 2001.

[62] I. Bulow Pedersen, N. Knudsen, A. Carlé et al., "A cautious iodization programme bringing iodine intake to a low recommended level is associated with an increase in the prevalence of thyroid autoantibodies in the population," Clinical Endocrinology, vol. 75, no. 1, pp. 120-126, 2011.

[63] L. K. H. Koh, F. S. Greenspan, and P. P. B. Yeo, "Interferon- $\alpha$ induced thyroid dysfunction: three clinical presentations and a review of the literature," Thyroid, vol. 7, no. 6, pp. 891-896, 1997.

[64] B. Contempre, J. F. Denef, J. E. Dumont, and M. C. Many, "Selenium deficiency aggravates the necrotizing effects of a high iodide dose in iodine deficient rats," Endocrinology, vol. 132, no. 4, pp. 1866-1868, 1993.

[65] M. P. Rayman, "The importance of selenium to human health," The Lancet, vol. 356, no. 9225, pp. 233-241, 2000.

[66] R. Gärtner, B. C. H. Gasnier, J. W. Dietrich, B. Krebs, and M. W. A. Angstwurm, "Selenium supplementation in patients with autoimmune thyroiditis decreases thyroid peroxidase antibodies concentrations," The Journal of Clinical Endocrinology \& Metabolism, vol. 87, no. 4, pp. 1687-1691, 2002.

[67] P. Laurberg, G. Wallin, L. Tallstedt, M. Abraham-Nordling, G. Lundell, and O. Törring, "TSH-receptor autoimmunity in Graves' disease after therapy with anti-thyroid drugs, surgery, or radioiodine: a 5-year prospective randomized study," European Journal of Endocrinology, vol. 158, no. 1, pp. 69-75, 2008.

[68] D. Reinwein, G. Benker, J. H. Lazarus et al., "A prospective randomized trial of antithyroid drug dose in Graves' disease therapy. European Multicenter Study Group on Antithyroid Drug Treatment," The Journal of Clinical Endocrinology \& Metabolism, vol. 76, no. 6, pp. 1516-1521, 1993.

[69] A. W. C. Kung, K. S. Lau, and L. D. Kohn, "Characterization of thyroid-stimulating blocking antibodies that appeared during transient hypothyroidism after radioactive iodine therapy," Thyroid, vol. 10, no. 10, pp. 909-917, 2000.

[70] A. Pinchera, P. Liberti, E. Martino et al., "Effects of antithyroid therapy on the long-acting thyroid stimulator and the antithyroglobulin antibodies," The Journal of Clinical Endocrinology of Metabolism, vol. 29, no. 2, pp. 231-238, 1969. 
[71] L. J. DeGroot, "Radioiodine and the immune system," Thyroid, vol. 7, pp. 259-264, 1997.

[72] W. Wang, W. Teng, Z. Shan et al., "The prevalence of thyroid disorders during early pregnancy in China: the benefits of universal screening in the first trimester of pregnancy," European Journal of Endocrinology, vol. 164, no. 2, pp. 263-268, 2011.

[73] U. Feldt-Rasmussen, M. Hoier-Madsen, N. G. Rasmussen, L. Hegedus, and P. Hornnes, "Anti-thyroid peroxidase antibodies during pregnancy and postpartum. Relation to postpartum thyroiditis," Autoimmunity, vol. 6, no. 3, pp. 211-214, 1990.

[74] T. Shiina, H. Inoko, and J. K. Kulski, "An update of the HLA genomic region, locus information and disease associations: 2004," Tissue Antigens, vol. 64, no. 6, pp. 631-649, 2004.

[75] Y. Ban, T. F. Davies, D. A. Greenberg et al., "Arginine at position 74 of the HLA-DR $\beta 1$ chain is associated with Graves' disease," Genes and Immunity, vol. 5, no. 3, pp. 203-208, 2004.

[76] T. Tilburgs, S. A. Scherjon, and F. H. J. Claas, "Major histocompatibility complex (MHC)-mediated immune regulation of decidual leukocytes at the fetal-maternal interface," Journal of Reproductive Immunology, vol. 85, no. 1, pp. 58-62, 2010.

[77] B. Favier, J. LeMaoult, N. Rouas-Freiss, P. Moreau, C. Menier, and E. D. Carosella, "Research on HLA-G: an update," Tissue Antigens, vol. 69, no. 3, pp. 207-211, 2007.

[78] D. A. Kahn and D. Baltimore, "Pregnancy induces a fetal antigen-specific maternal $\mathrm{T}$ regulatory cell response that contributes to tolerance," Proceedings of the National Academy of Sciences of the United States of America, vol. 107, no. 20, pp. 9299-9304, 2010.

[79] M. Kühnert, R. Strohmeier, M. Stegmüller, and E. Halberstadt, "Changes in lymphocyte subsets during normal pregnancy," European Journal of Obstetrics \& Gynecology and Reproductive Biology, vol. 76, no. 2, pp. 147-151, 1998.

[80] T. G. Wegmann, H. Lin, L. Guilbert, and T. R. Mosmann, "Bidirectional cytokine interactions in the maternal-fetal relationship: is successful pregnancy a TH2 phenomenon?" Immunology Today, vol. 14, no. 7, pp. 353-356, 1993.

[81] G. Chaouat, “The Th1/Th2 paradigm: still important in pregnancy?" Seminars in Immunopathology, vol. 29, no. 2, pp. 95-113, 2007.

[82] L. R. Guerin, J. R. Prins, and S. A. Robertson, "Regulatory T-cells and immune tolerance in pregnancy: a new target for infertility treatment?" Human Reproduction Update, vol. 15, no. 5, pp. 517-535, 2009.

[83] A. Leber, A. Teles, and A. C. Zenclussen, "Regulatory T cells and their role in pregnancy," American Journal of Reproductive Immunology, vol. 63, no. 6, pp. 445-459, 2010.

[84] S. Saito, T. Shima, A. Nakashima, A. Shiozaki, M. Ito, and Y. Sasaki, "What is the role of regulatory T cells in the success of implantation and early pregnancy?" Journal of Assisted Reproduction and Genetics, vol. 24, no. 9, pp. 379-386, 2007.

[85] S. Thangaratinam, A. Tan, E. Knox, M. D. Kilby, J. Franklyn, and A. Coomarasamy, "Association between thyroid autoantibodies and miscarriage and preterm birth: meta-analysis of evidence," British Medical Journal, vol. 342, no. 7806, p. d2616, 2011.

[86] W. Levinson, Review of Medical Microbiology and Immunology, McGraw-Hill Medical, New York, NY, USA, 11th edition, 2010.

[87] P. W. Kincade, K. L. Medina, G. Smithson, and D. C. Scott, "Pregnancy: a clue to normal regulation of B lymphopoiesis," Immunology Today, vol. 15, no. 11, pp. 539-544, 1994.

[88] J. D. Bouaziz, K. Yanaba, and T. F. Tedder, "Regulatory B cells as inhibitors of immune responses and inflammation," Immunological Reviews, vol. 224, no. 1, pp. 201-214, 2008.
[89] K. Poppe, B. Velkeniers, and D. Glinoer, "The role of thyroid autoimmunity in fertility and pregnancy," Nature Clinical Practice Endocrinology \& Metabolism, vol. 4, no. 7, pp. 394-405, 2008.

[90] K. Poppe, B. Velkeniers, and D. Glinoer, "Thyroid disease and female reproduction," Clinical Endocrinology, vol. 66, no. 3, pp. 309-321, 2007.

[91] G. Grassi, A. Balsamo, C. Ansaldi, A. Balbo, M. Massobrio, and C. Benedetto, "Thyroid autoimmunity and infertility," Gynecological Endocrinology, vol. 15, no. 5, pp. 389-396, 2001.

[92] D. Glinoer, M. F. Soto, P. Bourdoux et al., "Pregnancy in patients with mild thyroid abnormalities: maternal and neonatal repercussions," The Journal of Clinical Endocrinology \& Metabolism, vol. 73, no. 2, pp. 421-427, 1991.

[93] A. de Vivo, A. Mancuso, A. Giacobbe et al., "Thyroid function in women found to have early pregnancy loss," Thyroid, vol. 20, no. 6, pp. 633-637, 2010.

[94] M. F. Prummel and W. M. Wiersinga, "Thyroid autoimmunity and miscarriage," European Journal of Endocrinology, vol. 150, no. 6, pp. 751-755, 2004.

[95] R. Negro, G. Formoso, T. Mangieri, A. Pezzarossa, D. Dazzi, and H. Hassan, "Levothyroxine treatment in euthyroid pregnant women with autoimmune thyroid disease: effects on obstetrical complications," The Journal of Clinical Endocrinology of Metabolism, vol. 91, no. 7, pp. 2587-2591, 2006.

[96] V. H. Eisenberg, M. Zolti, and D. Soriano, "Is there an association between autoimmunity and endometriosis?" Autoimmunity Reviews, vol. 11, no. 11, pp. 806-814, 2012.

[97] K. Poppe, D. Glinoer, A. van Steirteghem et al., "Thyroid dysfunction and autoimmunity in infertile women," Thyroid, vol. 12, no. 11, pp. 997-1001, 2002.

[98] G. Matarese, G. de Placido, Y. Nikas, and C. Alviggi, "Pathogenesis of endometriosis: natural immunity dysfunction or autoimmune disease?" Trends in Molecular Medicine, vol. 9, no. 5, pp. 223-228, 2003.

[99] E. Konova, "The role of NK cells in the autoimmune thyroid disease-associated pregnancy loss," Clinical Reviews in Allergy \& Immunology, vol. 39, no. 3, pp. 176-184, 2010.

[100] E. Geva, N. Vardinon, J. B. Lessing et al., "Organ-specific autoantibodies are possible markers for reproductive failure: a prospective study in an in-vitro fertilization-embryo transfer programme," Human Reproduction, vol. 11, no. 8, pp. 1627-1631, 1996.

[101] K. Poppe, D. Glinoer, H. Tournaye et al., "Assisted reproduction and thyroid autoimmunity: an unfortunate combination?" The Journal of Clinical Endocrinology \& Metabolism, vol. 88, no. 9, pp. 4149-4152, 2003.

[102] R. Negro, T. Mangieri, L. Coppola et al., "Levothyroxine treatment in thyroid peroxidase antibody-positive women undergoing assisted reproduction technologies: a prospective study," Human Reproduction, vol. 20, no. 6, pp. 1529-1533, 2005.

[103] B. Velkeniers, A. van Meerhaeghe, K. Poppe, D. Unuane, H. Tournaye, and P. Haentjens, "Levothyroxine treatment and pregnancy outcome in women with subclinical hypothyroidism undergoing assisted reproduction technologies: systematic review and meta-analysis of RCTs," Human Reproduction Update, 2013.

[104] H. Yoshida, N. Amino, K. Yagawa et al., "Association of serum antithyroid antibodies with lymphocytic infiltration of the thyroid gland: studies of seventy autopsied cases," The Journal of Clinical Endocrinology \& Metabolism, vol. 46, no. 6, pp. 859$862,1978$. 
[105] J. H. Lazarus, J. P. Bestwick, S. Channon et al., "Antenatal thyroid screening and childhood cognitive function," The New England Journal of Medicine, vol. 366, pp. 493-501, 2012.

[106] M. N. Montoro, "Management of hypothyroidism during pregnancy," Clinical Obstetrics and Gynecology, vol. 40, no. 1, pp. 6580, 1997.

[107] J. S. Dallas, "Autoimmune thyroid disease and pregnancy: relevance for the child," Autoimmunity, vol. 36, no. 6-7, pp. 339-350, 2003.

[108] J. E. Haddow, G. E. Palomaki, W. C. Allan et al., "Maternal thyroid deficiency during pregnancy and subsequent neuropsychological development of the child," The New England Journal of Medicine, vol. 341, no. 8, pp. 549-555, 1999.

[109] V. J. Pop, E. de Vries, A. L. van Baar et al., "Maternal thyroid peroxidase antibodies during pregnancy: a marker of impaired child development?" The Journal of Clinical Endocrinology \& Metabolism, vol. 80, no. 12, pp. 3561-3566, 1995.

[110] R. Núñez Miguel, "Analysis of the thyrotropin receptor-thyrotropin interaction by comparative modeling," Thyroid, vol. 14, no. 12, pp. 991-1011, 2004.

[111] E. B. Man, "Thyroid function in pregnancy and infancy. Maternal hypothyroxinemia and retardation of progeny," CRC Critical Reviews in Clinical Laboratory Sciences, vol. 3, no. 2, pp. 203$225,1972$.

[112] Y. Li, Z. Shan, W. Teng et al., "Abnormalities of maternal thyroid function during pregnancy affect neuropsychological development of their children at 25-30 months," Clinical Endocrinology, vol. 72, no. 6, pp. 825-829, 2010.

[113] V. J. Pop, E. P. Brouwers, H. L. Vader, T. Vulsma, A. L. van Baar, and J. J. de Vijlder, "Maternal hypothyroxinaemia during early pregnancy and subsequent child development: a 3-year followup study," Clinical Endocrinology, vol. 59, no. 3, pp. 282-288, 2003.

[114] M. Abbassi-Ghanavati, B. M. Casey, C. Y. Spong, D. D. McIntire, L. M. Halvorson, and F. G. Cunningham, "Pregnancy outcomes in women with thyroid peroxidase antibodies," Obstetrics and Gynecology, vol. 116, no. 2, pp. 381-386, 2010.

[115] X. He, P. Wang, Z. Wang, X. He, D. Xu, and B. Wang, “Thyroid antibodies and risk of preterm delivery: a meta-analysis of prospective cohort studies," European Journal of Endocrinology, vol. 167, pp. 455-464, 2012.

[116] J. Y. Chong, L. P. Rowland, and R. D. Utiger, "Hashimoto encephalopathy: syndrome or myth?” Archives of Neurology, vol. 60, no. 2, pp. 164-171, 2003.

[117] L. D. K. E. Premawardhana, A. B. Parkes, R. John, B. Harris, and J. H. Lazarus, "Thyroid peroxidase antibodies in early pregnancy: utility for prediction of postpartum thyroid dysfunction and implications for screening," Thyroid, vol. 14, no. 8, pp. 610615,2004 .

[118] A. Stagnaro-Green, M. Abalovich, E. Alexander et al., "Guidelines of the American Thyroid Association for the diagnosis and management of thyroid disease during pregnancy and postpartum," Thyroid, vol. 21, no. 10, pp. 1081-1125, 2011.

[119] J. H. Lazarus, R. Hall, S. Othman et al., "The clinical spectrum of postpartum thyroid disease," QJM, vol. 89, no. 6, pp. 429-435, 1996.

[120] W. K. Nicholson, K. A. Robinson, R. C. Smallridge, P. W. Ladenson, and N. R. Powe, "Prevalence of postpartum thyroid dysfunction: a quantitative review," Thyroid, vol. 16, no. 6, pp. 573-582, 2006.
[121] J. H. Lazarus, A. B. Parkes, and L. D. K. E. Premawardhana, "Postpartum thyroiditis," Autoimmunity, vol. 35, no. 3, pp. 169173, 2002.

[122] A. Stagnaro-Green, A. Schwartz, R. Gismondi, A. Tinelli, T. Mangieri, and R. Negro, "High rate of persistent hypothyroidism in a large-scale prospective study of postpartum thyroiditis in Southern Italy," The Journal of Clinical Endocrinology \& Metabolism, vol. 96, no. 3, pp. 652-657, 2011.

[123] B. G. A. Stuckey, G. N. Kent, L. C. Ward, S. J. Brown, and J. P. Walsh, "Postpartum thyroid dysfunction and the long-term risk of hypothyroidism: results from a 12-year follow-up study of women with and without postpartum thyroid dysfunction," Clinical Endocrinology, vol. 73, no. 3, pp. 389-395, 2010.

[124] S. A. Morshed, R. Latif, and T. F. Davies, "Delineating the autoimmune mechanisms in Graves' disease," Immunologic Research, vol. 54, no. 1-3, p. 191, 2012.

[125] S. C. Werner, S. H. Ingbar, L. E. Braverman, and R. D. Utiger, Werner \& Ingbar's the Thyroid : A Fundamental and Clinical Text, Lippincott Williams \& Wilkins, Philadelphia, Pa, USA, 9th edition, 2005.

[126] B. Rapoport, G. D. Chazenbalk, J. C. Jaume, and S. M. Mclachlan, "The thyrotropin (TSH)-releasing hormone receptor: interaction with TSH and autoantibodies," Endocrine Reviews, vol. 19, no. 6, pp. 673-716, 1998.

[127] T. Davies, R. Marians, and R. Latif, “The TSH receptor reveals itself," The Journal of Clinical Investigation, vol. 110, no. 2, pp. 161-164, 2002.

[128] B. R. Smith, J. Sanders, and J. Furmaniak, “TSH receptor antibodies," Thyroid, vol. 17, no. 10, pp. 923-938, 2007.

[129] D. D. Adams, "Pathogenesis of the hyperthyroidism of Graves's disease," British Medical Journal, vol. 1, no. 5441, pp. 1015-1019, 1965.

[130] P. Kendall-Taylor, S. M. Dirmikis, and D. S. Munro, "Longacting thyroid stimulator and related factors," Proceedings of the Royal Society of Medicine, vol. 68, no. 4, pp. 252-253, 1975.

[131] B. R. Smith and R. Hall, "Thyroid stimulating immunoglobulins in Graves' disease," The Lancet, vol. 2, no. 7878, pp. 427-431, 1974.

[132] J. Sanders, M. Evans, L. D. K. E. Premawardhana et al., "Human monoclonal thyroid stimulating autoantibody," The Lancet, vol. 362, no. 9378, pp. 126-128, 2003.

[133] S. A. Morshed, R. Latif, and T. F. Davies, "Characterization of thyrotropin receptor antibody-induced signaling cascades," Endocrinology, vol. 150, no. 1, pp. 519-529, 2009.

[134] N. Takasu, T. Yamada, M. Takasu et al., "Disappearance of thyrotropin-blocking antibodies and spontaneous recovery from hypothyroidism in autoimmune thyroiditis," The New England Journal of Medicine, vol. 326, no. 8, pp. 513-518, 1992.

[135] S. A. Morshed, K. Michalek, R. Latif, and T. F. Davies, "TSH receptor autoantibodies," Autoimmunity Reviews, vol. 9, no. 2, pp. 113-116, 2009.

[136] J. C. Jaume, A. Kakinuma, G. D. Chazenbalk, B. Rapoport, and S. M. McLachlan, "Thyrotropin receptor autoantibodies in serum are present at much lower levels than thyroid peroxidase autoantibodies: analysis by flow cytometry," The Journal of Clinical Endocrinology \& Metabolism, vol. 82, no. 2, pp. 500-507, 1997.

[137] M. Schott, N. G. Morgenthaler, R. Fritzen et al., "Levels of autoantibodies against human TSH receptor predict relapse of hyperthyroidism in Graves' disease," Hormone and Metabolic Research, vol. 36, no. 2, pp. 92-96, 2004. 
[138] D. C. Matthews and A. A. Syed, "The role of TSH receptor antibodies in the management of Graves' disease," European Journal of Internal Medicine, vol. 22, no. 3, pp. 213-216, 2011.

[139] K. Zöphel, D. Roggenbuck, and M. Schott, "Clinical review about TRAb assay's history," Autoimmunity Reviews, vol. 9, no. 10, pp. 695-700, 2010.

[140] C. Kamath, M. A. Adlan, and L. D. Premawardhana, "The role of thyrotrophin receptor antibody assays in Graves' disease," Journal of Thyroid Research, vol. 2012, Article ID 525936, 8 pages, 2012.

[141] H. Tamaki, E. Itoh, T. Kaneda et al., "Crucial role of serum human chorionic gonadotropin for the aggravation of thyrotoxicosis in early pregnancy in Graves' disease," Thyroid, vol. 3, no. 3, pp. 189-193, 1993.

[142] N. Amino, O. Tanizawa, and H. Mori, "Aggravation of thyrotoxicosis in early pregnancy and after delivery in Graves' disease," The Journal of Clinical Endocrinology \& Metabolism, vol. 55, no. 1, pp. 108-112, 1982.

[143] G. W. Chan and S. J. Mandel, "Therapy Insight: management of Graves' disease during pregnancy," Nature Clinical Practice Endocrinology \& Metabolism, vol. 3, no. 6, pp. 470-478, 2007.

[144] R. H. Parker and W. H. Beierwaltes, "Thyroid antibodies during pregnancy and in the newborn," The Journal of Clinical Endocrinology \& Metabolism, vol. 21, pp. 792-798, 1961.

[145] M. Zakarija and J. M. McKenzie, "Pregnancy-associated changes in the thyroid-stimulating antibody of Graves' disease and the relationship to neonatal hyperthyroidism," The Journal of Clinical Endocrinology \& Metabolism, vol. 57, no. 5, pp. 10361040, 1983.

[146] J. I. Hamburger, "Diagnosis and management of Graves' disease in pregnancy," Thyroid, vol. 2, no. 3, pp. 219-224, 1992.

[147] A. W. C. Kung and B. M. Jones, "A change from stimulatory to blocking antibody activity in Graves' disease during pregnancy," The Journal of Clinical Endocrinology \& Metabolism, vol. 83, no. 2, pp. 514-518, 1998.

[148] R. S. Brown, "Maternal thyrotropin receptor-blocking antibodies and the fetus: current perspectives," Current Opinion in Endocrinology \& Diabetes, vol. 12, no. 1, pp. 1-3, 2005.

[149] N. Amino, Y. Izumi, Y. Hidaka et al., "No increase of blocking type anti-thyrotropin receptor antibodies during pregnancy in patients with Graves' disease," The Journal of Clinical Endocrinology \& Metabolism, vol. 88, no. 12, pp. 5871-5874, 2003.

[150] Y. Hidaka, H. Tamaki, Y. Iwatani, H. Tada, N. Mitsuda, and N. Amino, "Prediction of post-partum Graves' thyrotoxicosis by measurement of thyroid stimulating antibody in early pregnancy," Clinical Endocrinology, vol. 41, no. 1, pp. 15-20, 1994.

[151] H. Tamaki, N. Amino, M. Aozasa et al., "Serial changes in thyroid-stimulating antibody and thyrotropin binding inhibitor immunoglobulin at the time of postpartum occurrence of thyrotoxicosis in Graves' disease," The Journal of Clinical Endocrinology \& Metabolism, vol. 65, no. 2, pp. 324-330, 1987.

[152] M. Polak, I. Legac, E. Vuillard, J. Guibourdenche, M. Castanet, and D. Luton, "Congenital hyperthyroidism: the fetus as a patient," Hormone Research, vol. 65, no. 5, pp. 235-242, 2006.

[153] J. M. McKenzie and M. Zakarija, "Fetal and neonatal hyperthyroidism and hypothyroidism due to maternal TSH receptor antibodies," Thyroid, vol. 2, no. 2, pp. 155-159, 1992.

[154] J. Kratzsch and F. Pulzer, "Thyroid gland development and defects," Best Practice and Research in Clinical Endocrinology and Metabolism, vol. 22, no. 1, pp. 57-75, 2008.
[155] M. Polak, "Hyperthyroidism in early infancy: pathogenesis, clinical features and diagnosis with a focus on neonatal hyperthyroidism," Thyroid, vol. 8, no. 12, pp. 1171-1177, 1998.

[156] J. M. Mckenzie, "Neonatal Graves' disease," The Journal of Clinical Endocrinology \& Metabolism, vol. 24, pp. 660-668, 1964.

[157] D. Peleg, S. Cada, A. Peleg, and M. Ben-Ami, “The relationship between maternal serum thyroid-stimulating immunoglobulin and fetal and neonatal thyrotoxicosis," Obstetrics and Gynecology, vol. 99, no. 6, pp. 1040-1043, 2002.

[158] M. Zakarija, J. M. McKenzie, and M. S. Eidson, “Transient neonatal hypothyroidism: characterization of maternal antibodies to the thyrotropin receptor," The Journal of Clinical Endocrinology \& Metabolism, vol. 70, no. 5, pp. 1239-1246, 1990.

[159] C. Evans, N. J. Jordan, G. Owens, D. Bradley, M. Ludgate, and R. John, "Potent thyrotrophin receptor-blocking antibodies: a cause of transient congenital hypothyroidism and delayed thyroid development," European Journal of Endocrinology, vol. 150, no. 3, pp. 265-268, 2004.

[160] R. S. Brown, R. L. Bellisario, D. Botero et al., "Incidence of transient congenital hypothyroidism due to maternal thyrotropin receptor-blocking antibodies in over one million babies," The Journal of Clinical Endocrinology \& Metabolism, vol. 81, no. 3, pp. 1147-1151, 1996.

[161] S. Endocrine, American Association of Clinical Endocrinologists, Asia et al., "Management of thyroid dysfunction during pregnancy and postpartum: an Endocrine Society Clinical Practice Guideline," Thyroid, vol. 17, no. 11, pp. 1159-1167, 2007. 


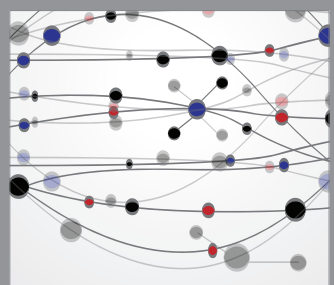

The Scientific World Journal
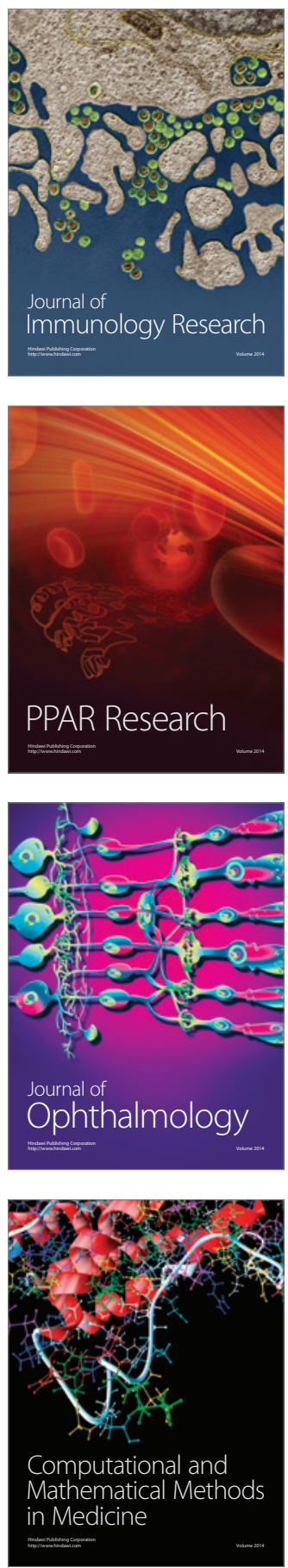

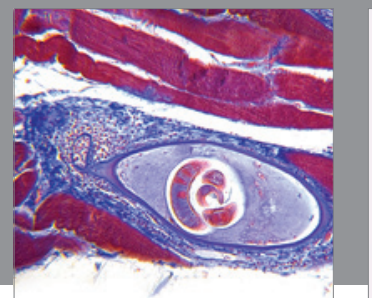

Gastroenterology

Research and Practice
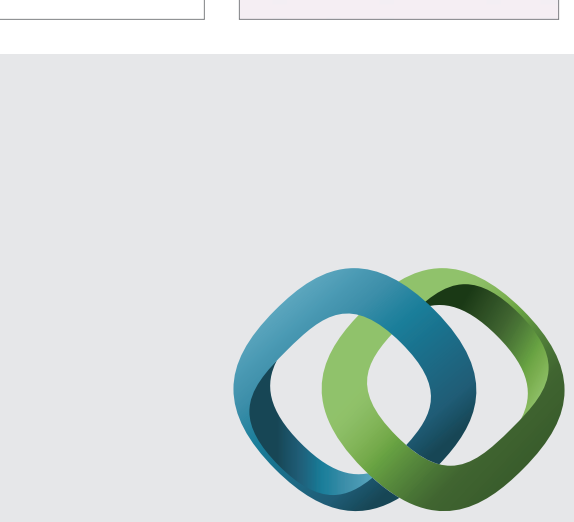

\section{Hindawi}

Submit your manuscripts at

http://www.hindawi.com
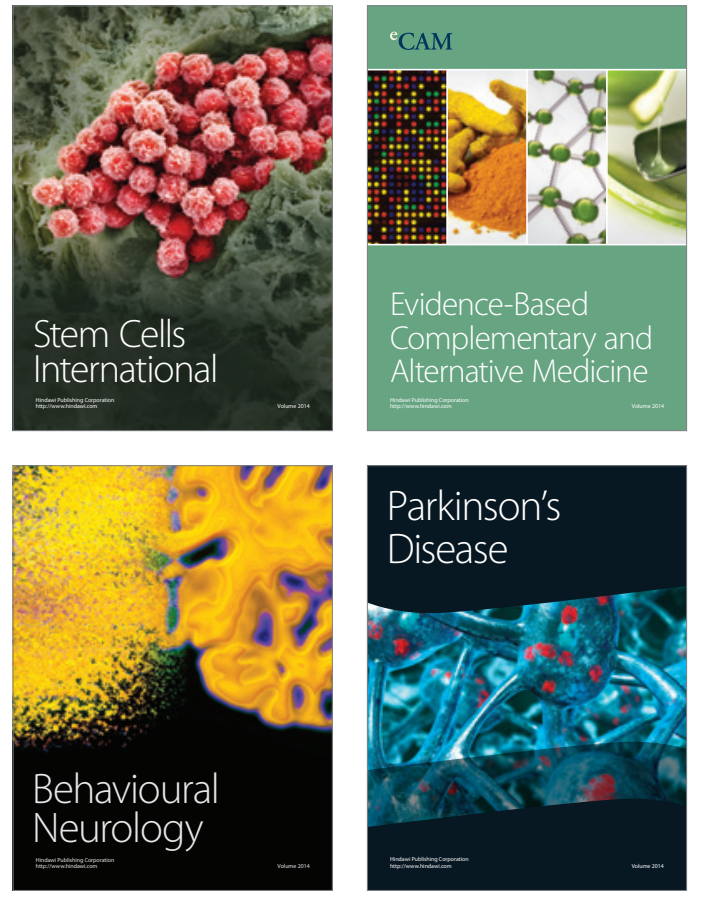
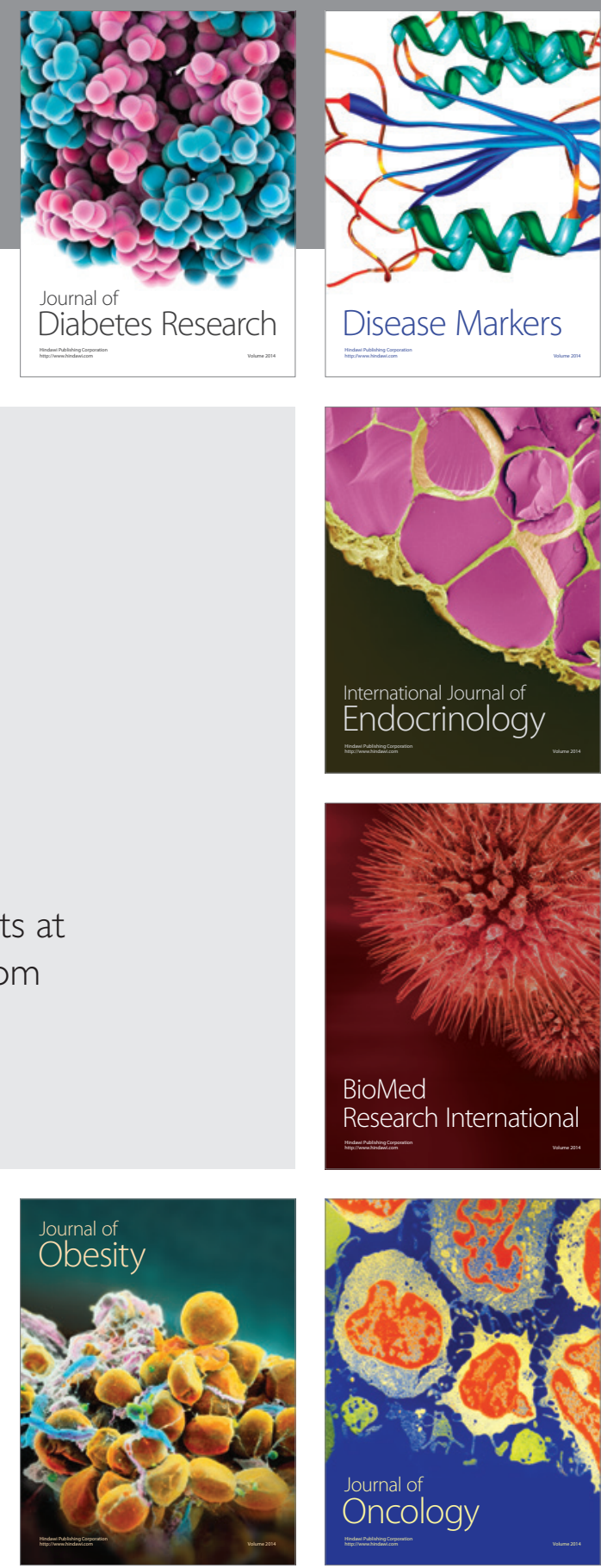

Disease Markers
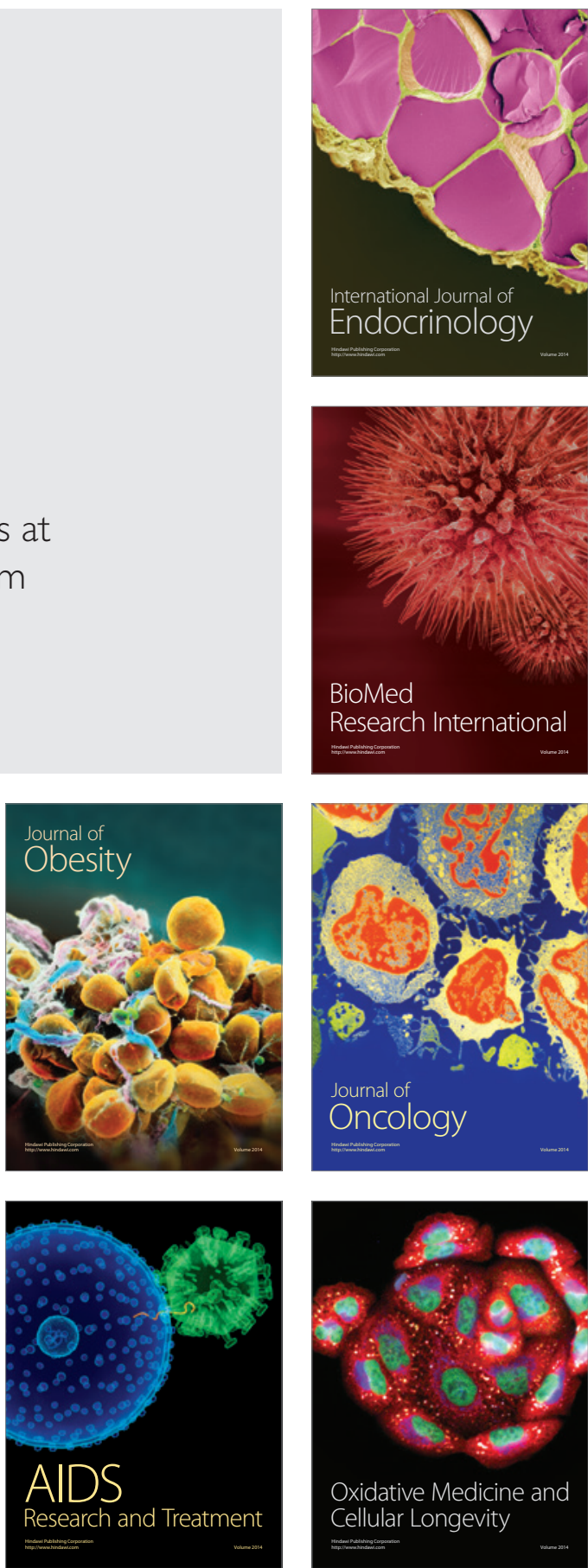